\title{
Adverse Selection and the Performance of Private Equity Co-Investments
}

\author{
Reiner Braun \\ Technical University of Munich (TUM), Germany* \\ Tim Jenkinson \\ Saïd Business School, University of Oxford, UK \\ Christoph Schemmerl \\ Technical University of Munich (TUM), Germany
}

\begin{abstract}
Investors increasingly look for private equity managers to provide opportunities for co-investing outside the fund structure, thereby saving fees and carried interest payments. In this paper we use a large sample of buyout and venture capital coinvestments to test how such deals compare with the remaining fund investments. In contrast to Fang, Ivashina and Lerner (2015) we find no evidence of adverse selection. Gross return distributions of co-investments and other deals are similar. Coinvestments generally have lower costs to investors. We simulate net returns to investors and demonstrate how reasonably sized portfolios of co-investments significantly out-perform fund returns.
\end{abstract}

December 2018

Keywords: private equity, financial intermediation, co-investment, adverse selection

JEL classification: G23, G24

\footnotetext{
Contact information: Reiner Braun: reiner.braun@tum.de ; Tim Jenkinson: tim.jenkinson@sbs.ox.ac.uk ; Christoph Schemmerl: christoph.schemmerl@tum.de

We are grateful to Josh Lerner, Niklas Huether, Konrad Raff and seminar participants at the Private Equity Research Consortium Conference at the University of North Carolina at Chapel Hill, the Risk Management Symposium at the Said Business School, University of Oxford, the Private Equity Symposium at London Business School, the European Finance Association (EFA) Annual Meeting and the TUM School of Management Brownbag Seminar for valuable comments. We also gratefully acknowledge research assistance from Alexander Sigel and Niklas Huke. We thank seven Limited Partners for sharing their data on co-investments. Two of the authors have advised institutional investors in private equity funds or private equity groups. All errors and omissions are our own.
} 


\section{Introduction}

Private equity investments can take many forms, but the vast majority of the money has, to date, been invested via funds operated by private equity managers. These funds are typically established, for tax and other reasons, as closed-end funds structured as limited partnerships with a finite life. Such funds are so-called "blind pools" of capital. The investors, as limited partners (LPs) of the fund, commit capital but delegate investment decisions to the private equity manager, as the general partner (GP). However, investors increasingly seek the opportunity to make investments in portfolio companies outside a fund structure - known as co-investments. In a recent survey, one-half of private equity investors reported that they made co-investments and three-quarters of these investors intended to increase or maintain their current level of co-investment activity. ${ }^{1}$ Given that the fund managers can choose which investments to offer for co-investment, this raises the possibility that there may be a selected sample - either positively or negatively - relative to the deals that are not offered. In this paper we analyse, using the largest dataset of such deals yet assembled, whether there is evidence of selection and how investor returns compare, net of fees and carried interest, from investing in funds relative to constructing portfolios of co-investments.

There are various motivations behind investor interest in co-investments. First, although private equity returns have historically outperformed public market benchmarks (Harris, Jenkinson and Kaplan (2014)), the returns of private and public equity have been converging (Harris, Jenkinson and Kaplan (2016)). This has increased the pressure on private equity fee structures. As has been documented by various authors (Metrick and Yasuda (2010), Phalippou (2009)) the impact of management fees and carried interest payments on net returns is significant. One

\footnotetext{
${ }^{1}$ See Preqin Private Equity Spotlight, LP Survey on Co-investments, November 2015, which surveyed 222 active LPs.
} 
important attraction of co-investments is the absence, or much lower levels, of fees and carry. Coinvestments therefore bring down the average cost of investing in private equity and provide the potential for increased net returns.

Second, co-investments give the opportunity for LPs to increase their exposure - above the pro rata interest obtained via their fund investment - in particular companies or sectors. This may be driven by a belief that investors can spot particularly attractive portfolio companies. Alternatively, investors may use co-investment to tilt their portfolio towards particular sectors such as new technologies - that are difficult to gain exposure to via public markets. While coinvestments allow investors greater control, this also requires them to have the relevant skills and experience to evaluate which transactions to participate in. To some extent, this involves duplicating the skills that already exist in the fund manager, and increases the costs for investors, although managing a co-investment program can be out-sourced to specialised intermediaries. ${ }^{2}$

Finally, participating in co-investments may strengthen and deepen an investor's relationship with GPs. This may be particularly valuable in the case of successful GPs whose funds are over-subscribed and where investor participation in the main fund is rationed. Co-investment opportunities are also sometimes offered to investors who are not limited partners in the private equity fund. This can provide valuable information to such investors, who are able to observe at close quarters the way GPs perform due diligence, structure deals, and the discipline of their investment approach. The experience of participating alongside a GP in a specific transaction can help inform decisions about whether to commit capital to future funds.

\footnotetext{
2 Probitas Partners' Private Equity Institutional Investor Trends survey for 2017 reports that $42 \%$ of investors manage co-investments internally and a further $13 \%$ of investors participate in an out-sourced co-investment program.
} 
While the potential attractions of co-investments to investors are clear, why do GPs offer them in the first place? There are several possible reasons.

First, given the investor pressure ${ }^{3}$ to reduce the overall cost of private equity investing, GPs may prefer the indirect route of promising co-investment opportunities to the more direct approach of, ex ante, reducing fees or carried interest payments. While the economics of a fund charging higher fees/carry but offering a proportion of co-investment could be identical to that of a fund charging lower fees and not offering co-investment, the former gives the GP more discretion to price discriminate. Many asset owners focus the attention of their investment staff on choosing fund managers, to whom investment decisions at the portfolio company level are delegated, rather than picking individual deals. It is likely that the more sophisticated, well-resourced investors run co-investment programs, and, for GPs, this may be a way of discriminating in their favor. More direct discrimination between investors, by offering different fund terms, is increasingly difficult as "most favoured nation" clauses have become a common feature of fund partnership agreements.

Second, GPs may use co-investments to "curry favour" with existing or potential investors. GPs raise a new fund every few years, and so co-investments may be used at critical times in the fundraising cycle to encourage existing LPs to participate in the GP's next fund. Similar motivations apply when co-investment opportunities are offered to potential investors (who have not made a commitment to the fund). The GP may use a co-investment deal as a 'taster' to tempt the investor to make a fund commitment in the future. However, there may also be other motivations. For instance, a particular investor might be very valuable to a deal if they have deep knowledge of a region or sector and therefore, through their due diligence and involvement, give

\footnotetext{
${ }^{3}$ For instance, the Institutional Limited Partners Association has been campaigning for better economic terms for investors.
} 
confidence to the GP and other potential co-investors in a deal. Since, in general, co-investments allow investors to free-ride, at least in part, on the costs being borne by the fund investors, the GP may allocate such benefits strategically towards target investors for future funds.

Third, all funds have limitations on the proportion of the fund that can be invested in any individual deal, and GPs are, in any case, concerned to construct well diversified portfolios of deals. Therefore, co-investment may allow the GP to participate in deals that are large relative to the fund size and that might otherwise be viewed as creating too concentrated an exposure. The alternative route of entering into a 'club deal' with other GPs on large deals has become less common since the U.S. Securities and Exchange Commission brought antitrust lawsuits against eleven large GPs alleging collusion. ${ }^{4}$ The recent growth in co-investment has certainly coincided with the growth of regulatory attention and the demise of GP club deals. ${ }^{5}$

Therefore, from the investor and private equity fund manager perspectives, co-investments offer potential benefits. The main concern facing investors is whether such deals are a selected sample of the underlying fund investments. GPs face conflicting economic incentives in their choice of whether to offer a particular deal for co-investment. If they believe the deal will perform well, and therefore generate carried interest payments, the incentive to reduce the fund's investment in the transaction by involving co-investors will be low. According to this logic, ceteris paribus, deals where the GP is less confident that returns will be good, or where risks are judged to be high, are more likely to be offered for co-investment.

\footnotetext{
4 The investigation, launched before the financial crisis in 2007, eventually came to an end in 2014 and resulted in settlements totaling around $\$ 590 \mathrm{~m}$ being paid.

${ }^{5}$ An interesting issue, beyond the scope of this paper, is whether co-investment deals themselves will become the subject of regulatory attention, given that they offer potential benefits only to selected investors, and may unfairly allocate costs, against the spirit of the ubiquitous most favoure nation clauses in limited partnership agreements.
} 
Conversely, given that the long-term economic value of a GP is driven by their ability to raise future funds (Chung, Sensoy, Stern and Weisbach (2012)), the reputational consequences of selecting the most marginal deals for co-investment could out-weigh any short-term incentives. Any such incentives for adverse selection clearly depend on the extent of any information asymmetries. In practice, investors are provided with extensive due diligence reports on the proposed deals, but GPs will usually possess additional softer information - maybe through extensive interaction with the management team - and may be better at evaluating the attractiveness of the deal. Furthermore, GPs often work on a deal for many months, and only in the final few weeks do they open the deal to potential co-investors. Therefore, investors face time pressures to assimilate the information provided and obtain authorization from their investment committees. Testing whether or not there is adverse selection of deals that are offered for coinvestment by GPs is the central question addressed in this paper.

Obtaining data on individual private equity investments, as opposed to fund-level data, is very challenging. Identifying which of these investments were offered for co-investment adds a further level of complexity. One data collection strategy is to obtain information directly from a sample of LPs who have made co-investments. This approach is taken by the only previous paper on the subject, Fang et al. (2015), who study both co-investments and solo investments (buying a private company without the involvement of a private equity fund). They obtain data from seven LPs who participated in solo investments and co-investments. Based on 103 co-investment observations, they conclude that "Co-investments underperform the corresponding funds with which they co-invest, due to an apparent adverse selection of transactions [..]" (Fang et al. (2015), p. 160). In contrast, direct investments perform well. 
However, obtaining data from a sample of (willing) LPs encounters limitations in terms of scale, heterogeneity and representativeness. In this study, we pursue a different strategy taking advantage of the largest, and most complete, dataset of deal-level private equity data currently available. This dataset, previously used by Braun, Jenkinson and Stoff (2017) in their analysis of the persistence of GP performance, has detailed cash-flow and other information at the portfolio company level, covering buyout and venture capital (VC) deals. By matching this sample with commercial datasets that identify the investors in individual deals, we build a broad and representative sample of 1,016 co-investments made by 458 investors. These deals were associated with 464 different funds which, in total, made 13,430 investments. Therefore, $7.6 \%$ of deals in our sample of funds were co-investments. Of course, the way our sample is constructed means that we observe co-investment deals that took place; we do not observe deals that GPs offered but which no LP took up. However, we present evidence that such occurances are, in practice, extremely unlikely, given the excess demand for co-investment opportunities. Consequently, the deals we observe are essentially those selected by the GPs.

We use this dataset to explore four main issues. First, we analyse the factors that determine whether GPs offer a deal for co-investment. Second, we compare the gross return distributions of co-investments with the remaining fund investments to test for selection biases. We argue that comparing gross returns (before fees and carried interest) is the cleanest way of testing for adverse selection by the GP. Third, we analyse whether particular types of investor - such as endowments, pension funds, insurance companies etc. - experience different returns. Finally, we consider the conditions under which investors will benefit from co-investing. Given the non-normal, skewed distribution of returns on individual deals, investors will, in expectation, only benefit from coinvesting if they construct portfolios of such deals. We simulate how large these portfolios should 
be. We also, at this stage, estimate net investor returns by allowing for reasonable management fee and carried interest structures, and the likely cost of operating a co-investment program.

Our main results are as follows. First, we find that the main factor influencing whether a deal is offered for co-investment is deal size, relative to fund size. Large deals are significantly more likely to be offered for co-investment, consistent with the view that GPs use this approach to limit single-deal exposure.

Second, we find no evidence of adverse selection. As we have timed cash flows for all the deals, we are able to produce distributions of public market equivalent (PME) returns (Kaplan and Schoar (2005)) for both co-investments and deals that remain wholly within the fund. This is the first paper to produce such evidence for a large sample of deals and investors. We find that gross PMEs for co-investments are similar to the returns on deals from the same fund that are not offered for co-investment. Our econometric model controls for potential drivers of returns, such as the year of investment, industry, which GP ran the deal, fund sequence etc. and we find no significant evidence of selection bias, either adverse or positive. These results are clearly very different to those of Fang et al. (2015), although our dataset is much larger and includes a much broader range of investors.

Third, even though, across the whole sample we find no selection biases, we consider whether returns differ across investor types (pension funds, endowments, insurance companies etc.) and investor characteristics (such as experience, relationship with the GP etc.). This allows us to test for a different variant of adverse selection: whether particular investors get better, and worse, returns. However, we find no significant differences between investor types, nor do we find that existing investors in the fund get better, or worse, returns than investors who are not LPs in 
the fund. The only significant effect is that investors with prior experience of co-investing achieve higher returns, but only in the case of VC deals.

Taken together, this lack of evidence for adverse selection is consistent with GPs being more influenced by their long-term reputation with investors, rather than acting opportunistically to reduce their exposure to deals that are the least attractive, either in expected return and/or risk.

Fourth, when we simulate reasonable fee structures, as well as investor costs, for both coinvestments and funds, we find that, on average, co-investments out-perform fund investments by a significant margin. The average buyout co-investment out-performs deals in the corresponding fund by between 0.10 and 0.29 in terms of (net) PME. The results for VC are similar, with, on average, co-investments out-performing the remaining fund investments by between 0.19 and 0.39 . While our paper provides the first academic evidence on such co-investment out-performance, this finding is in line with the general perception in, and recent survey results from, the PE industry. ${ }^{6}$

Finally, given the skewed distribution of deal-level returns, engaging in single coinvestments will, on average, deliver returns that are below the average fund return. Therefore, in the absence of skill in picking the best deals, the average investor will only benefit from coinvestments if they pursue a diversification strategy and construct a portfolio of deals. Our final result estimates how large such portfolios need to be. We show, using simulations of different portfolio sizes, that portfolios of 10 buyout deals on average out-perform fund returns, net of fees and costs. For VC the results suggest that larger portfolios, of 20 or more, deals are required, and that significant out-performance (relative to fund investing) is only achieved if the GPs do not charge fees and carried interest on the co-investments.

\footnotetext{
${ }^{6}$ In a recent survey among investors published in the Preqin Global Private Equity and Venture Capital Report in $2017,68 \%$ of LPs stated that their co-investments outperform their fund portfolio. $29 \%$ indicated the performance is similar and only $3 \%$ experience an underperformance of co-investments.
} 
The remainder of the paper proceeds as follows. In the next section we describe how we construct our sample and analyse what factors influence whether a deal is offered for coinvestment. In section 3, we test whether co-investments exhibit any selection biases. Section 4 simulates the net returns of co-investments for different fee structures and portfolio size scenarios. Section 5 discusses why our findings differ from Fang et al. (2015), and, as a robustness test of our results, mimics the data collection methods that they used. Section 6 concludes.

\section{Data}

There is no specific database of private equity co-investment transactions, and so we construct such a sample by using Capital IQ's broad transactions database. The latter does not include any information on deal-level returns and so we match the co-investment sample we generate with a proprietary deal-level database of cash-flows and returns. We describe these two steps in turn.

\subsection{Constructing the universe of co-investments}

Capital IQ provides the most comprehensive and representative data currently available on transactions and investors (see Strömberg (2007), Bernstein et al. (2016) and Fang et al. (2015)). Whilst Capital IQ provides a flag for a deal being a co-investment, the definition is unclear, and is not limited to private equity-backed deals. Consequently, we have to define and generate our sample manually. By definition, a private equity co-investment involves at least one GP and one other investor in the same company at the same time. Capital IQ designates deals as being private equity transactions when they involve at least one GP; around 180,000 such transactions are included in the database. ${ }^{7}$ We first filter these private equity deals according to whether they have

\footnotetext{
${ }^{7}$ We refer to the filter "Investment Firm Type" when screening for transactions in Capital IQ. We include transactions where investors are labelled as "PE/VC" and exclude those who meet the label "PE/VC (Fundless Only)".
} 
more than one investor (of any sort), which is a necessary condition for them being a coinvestment. We then manually screen each investor's business description provided by Capital IQ and, if needed, publicly available data, to determine their type. By this process, we identify 6,894 distinct investors. Most of these investors will also be LPs in the fund, but some are not investors in the current fund fund raised by the GP. However, to be included in the CapitalIQ definition of 'LP', investors must particiapate in at least one PE fund. We consider later whether returns differ across these two groups, and find that there are no significant differences. In the remainder of the paper we refer to investors as LPs irrespective of whether they participate in the current fund of the GP. Finally, we restrict the sample to 12,106 deals in which there are at least two investors including at least one GP and at least one LP. ${ }^{8}$

\subsection{Will there be deals that we miss because no LP chooses to invest?}

Our sample comprises co-investment deals that took place. However, there may have been deals that were offered as a co-investment by a GP, but were rejected by all investors. Missing such potential deals would matter when exploring whether there are selection biases in the deals offered by GPs - since it could be that inferior deals were offered but investors declined, en masse, to participate.

Ideally, it would be possible to observe complete lists of all deals offered as coinvestments. Unfortunately, no such data exists on an industry-wide level, although clearly each GP (LP) knows which deal they offered (were offered). However, demand for co-investment

\footnotetext{
${ }^{8}$ Capital IQ provides a list of investors who are LPs in at least one fund, but some of these are, in fact, mainly GPs. For instance, investment firms such as TowerBrook Capital Partners or CVC Capital Partners are included in the Capital IQ Limited Partners list. However, both firms are mainly known as GPs and so are excluded from our list of LPs.
} 
seriously exceeds the supply. Recall that around $8 \%$ of the deals in our sample are offered for coinvestment. As noted earlier, surveys suggest that one-half of investors have an active coinvestment program, and that this proportion has been rising steadily. If the average fund has 100 investors, and undertakes 20 investments, then there will be around 2 deals, on average, on offer as coinvestments with around 50 investors prepared to consider such opportunities. Furthermore, while the most common approach of LPs is to be "selective" in their approach to co-investment, surveys suggest that one-quarter of investors take a "passive" approach - essentially investing in every co-investment opportunity they are offered (Preqin (2015)). Therefore, the sheer excess demand, and existence of investors who stand ready to commit capital to all deals, means that our sample of deals will essentially reflect the choices of GPs.

However, this issue is important for the interpretation of our analysis, and so in order to determine whether the possibility of rejected co-investment opportunities is a relevant phenomenon, or rather just a theoretical possibility, we interviewed ten fund managers that offer co-investments. We asked them the following question: what proportion of co-investments, in your experience, has not been taken up by any investor. All ten fund managers stated that it has never happened in their organization. ${ }^{9}$ This is not to say, of course, that individual investors do not reject particular deals - indeed, several respondents remarked that this is a regular occurrence. Whether particular investors are able to add value by their decisions on which co-investment opportunities to accept (and reject) is an interesting question, but requires information that is not currently available. However, the sheer excess demand for co-investment opportunities means that GPs can, in practice, find LPs willing to participate in the co-investment deals they offer. Consequently, we

\footnotetext{
${ }^{9}$ We also asked a sample of institutional investors who actively participate in co-investments whether they were aware of any co-investment opportunities offered that were not taken up by at least one investor in the market. Again, all of them stated that they were not aware of any such cases.
} 
believe that our sample is suitable for addressing whether GPs offer selected samples of deals from their funds for co-investment, and is not biased by the choices made by LPs.

Before leaving this issue it is worth noting that our sample construction strategy - which searches across the whole universe of potential investors - is preferable, for addressing the issue of GP selection biases, to constructing a sample based on information from a small number of LPs. In particular, Fang et al. (2015) focus on 7 experienced LPs in their analysis, and so their sample reflects the decisions of GPs and this small number of investors. The poor performance of coinvestments that they report will clearly reflects the choices made by those particular investors, who may have rejected good deals that our sample should, in principle, capture.

\subsection{Combining the co-investments universe with our deal-level return sample}

Capital IQ has no information on deal returns. However, we draw on a proprietary database of about 25,000 private equity deals, for which cash-flows and (in the case of unrealised deals) the latest net asset values are available. This data was previously used by Braun, Jenkinson and Stoff (2017), and is derived from three large institutional fund-of-fund managers who gather detailed deal-level data in the course of their due diligence process. An important feature of the database is that it contains GPs' complete fund and deal history, irrespective of whether the fund-of-fund managers chose to invest in any particular fund. Therefore, the data is free from any selection biases resulting from the fund-of fund managers' choices. ${ }^{10}$

\footnotetext{
${ }^{10}$ For a more detailed discussion on the characteristics and potential biases of the database see Braun, Jenkinson and Stoff (2017).
} 
1,016 of the identified co-investments are in our performance database, and this forms the main sample for our paper. These co-investments involve 458 different LPs over the period 19812010. In 320 of the deals, more than one LP participated as a co-investor.

An important advantage of this way of constructing the sample is that we obtain not only a comprehensive list of co-investments, but we also have deal and return information on all other investments from the corresponding PE fund through which each co-investment was made. The co-investments in our sample originate from 464 different buyout and venture capital funds raised between 1978 and 2010. These funds invested in a total of 13,430 portfolio companies. Therefore, $7.6 \%$ of all investments in these funds are co-investments. This is consistent with a recent study by Cambridge Associates, who advise LPs on private equity investments and provide data on the sector, which estimates that co-investments account for "[..] upwards of 5\% of overall private investment activity [..]". ${ }^{11}$

Besides general information on the deals and funds, a key feature of this database is the availability of monthly gross cash flows between each portfolio company and the fund. This enables more relevant return measures, in particular PME returns, to be calculated. In order to analyse our central question - whether the portfolio companies offered for coinvestment have a selection bias - gross returns are ideal. To be clear, we have the cash flows (and any remaining net asset values) for all the deals undertaken by each of the funds in our sample. For those deals offered for co-investment there will be two equity investors: the fund and a separate special purpose vehicle (SPV), formed for the sole purpose of making the co-investment. We have information on the fund's gross returns. We do not have information on the SPV but, as we show in section 5, the

11 Cambridge Associates, "Making Waves: The Cresting Co-Investment Opportunity", http://40926u2govf9kuqen1ndit018su.wpengine.netdna-cdn.com/wp-content/uploads/2015/03/Making-Waves-TheCresting-Co-investment-Opportunity.pdf, 2015. 
differences between the cash flows between the fund and the co-investment SPV are marginal in practice. To address whether there is any selection bias we need comparable gross performance across all deals, before any fees or carried interest are charged. Net returns at the deal level will reflect any carried interest payments charged at the fund level, and will tend to attenuate the performance of good deals in funds which pay carry. Good deals in funds that do not exceed the hurdle rate for paying carried interest will have no such charge. Consequently, the cleanest way to test whether there is any bias in favour of offering bad, or good, deals for coinvestment is to focus on gross returns. ${ }^{12}$ This is what we do in section 3.

While the main focus of this paper is on any selection biases in the sample of coinvestment deals, the question of the ultimate returns to investors is, of course, interesting and will reflect the relative charges levied on the fund investments and the co-investments. These net returns are clearly relevant to investors and will inform their decision whether to participate in co-investments, which we address in section 4 using simulations for likely fees. However, we deliberately keep the two questions - adverse selection, and relative (net) investor outcomes - distinct.

\subsection{LP characteristics}

We also gather information regarding the experience and investor type for the LPs in our sample. Capital IQ provides information on LPs' primary country of origin, their investor type, as well as their related investments into private equity funds. Information on the later was cross-

\footnotetext{
12 The only complication encountered in using gross returns relates to fees charged to the portfolio companies. Some GPs charge such fees, which are then often used to offset management fees (see Phalippou, Rauch and Umber (2018)). These would be included in our gross return measures, as such fees are not separately identified in the cash flows. However, a given GP will either tend to levy such fees on all portfolio companies or on none, and so the issue largely disappears when comparing coinvestment returns to the returns on the remaining fund investments of the same GP. This is the approach we take in our empirical analysis.
} 
checked and merged with the Preqin fund investments data base. ${ }^{13}$ As of November 2015, the 458

LPs had made 20,604 private equity fund investments. The average LP in our sample has made 45 fund investments and started investing in private equity in 1996. These figures are in line with the merged datasets of other studies (see Lerner et al. (2007) and Sensoy et al. (2014)). We assign each LP into one of eight LP categories using the investor type and the related business description provided by Capital IQ. ${ }^{14}$

Information on our LP sample is presented in Table 1. Panel A shows the regional distribution. About $61 \%$ of the LPs in our sample have their primary location in North America and approximately $30 \%$ are in Europe. The remaining $9 \%$ are located in other parts of the world. The distribution across LP types is displayed in Panel B. Advisors are investment advisors that provide investment products, such as segregated accounts and multi-asset portfolios, to investors. This group represents $11.4 \%$ of all LPs in our sample. Banks/Financial Services are bank-affiliated entities as well as similar financial services companies (18.1\%). Endowments are public endowments, private endowments as well as foundations (3.9\%). Ten percent of all LPs in our sample are entities affiliated with insurance companies. Investment firms are hedge funds, fundof-funds and other investment firms and represent $19.4 \%$ of LPs in our sample. Pension funds include public sector pension funds as well as private pension funds (4.4\%). Sovereign wealth funds represent $0.9 \%$ of co-investing LPs in our sample. All other LPs that do not fit in one of the aforementioned categories are included in Others. This category is the largest one in terms of

\footnotetext{
${ }^{13}$ Capital IQ and Preqin provide the most comprehensive samples of fund investments by LPs, but neither data set is complete. Therefore, merging the two provides good coverage on this information.

${ }^{14}$ We make adjustments in case the information regarding the investment firm type does not express LPs inherent investment background as outlined in the business description. Unlike Lerner et al. (2007) and Sensoy et al. (2014), we do not distinguish between public pension funds and corporate pension funds.
} 
number of LPs (even though not in terms of invested capital) and includes family offices, ultra high net worth individuals, development banks, corporations as well as their affiliated investment arms.

In line with a recent study by Preqin (2015), we confirm that the distribution of coinvestments across LP types appears to be more fragmented than for traditional fund investments. Institutional investors who traditionally commit substantial amounts of capital to private equity, such as pension funds and endowments, play a less dominant role in the co-investment business than in the fund investment business. This can, in part, be explained by the challenges some traditional investors face in hiring a team to build a co-investment portfolio. The skills required are closer to those associated with GPs, and can be expensive to acquire. We control for LP-related characteristics in our return analyses.

Panel C shows that LP fund investment experience is correlated with direct investing experience. We sort investors into quartiles according to the number of direct investments they have participated in. The most experienced co-investors have also made the most fund investments.

\subsection{Sample summary statistics}

Table 2 provides deal-level descriptive statistics for the co-investment sample in comparison to the remaining deals in the funds that were not offered for co-investment. Panel A shows that we have 365 buyout and 651 VC co-investments representing, in total, \$28bn and \$6bn respectively of equity capital invested (by GPs). The median equity investment by GPs into deals that are offered for co-investment is slightly larger than that for the other deals. Co-investments occur, on average, a few months earlier in the life of the fund.

Panel B reveals that $70 \%$ of co-investments in our sample are made in North America, with $24 \%$ in Europe. Panel C shows how the sample evolves over time. There has been a steady growth 
in the size of deals and funds, mainly driven by the buyout side. Our sample covers a 30-year time period from 1981 to 2010 , and broadly coincides with the growth of the buyout and VC sectors. It is noticeable that the sample used in Fang et al. (2015) is much more recent. More than two-thirds of the co-investments in their sample were made after 2004, whereas transactions from this period only represent one fifth of our sample.

In Panel D we classify deals according to their realization status. 54\% of the co-investment sample is fully realized, $13 \%$ of deals are partially realized and $33 \%$ are unrealized. For the latter two categories we have the latest net asset values reported by the GP, and use these in our return calculations. Past research has shown that these are, if anything, conservative estimates of the future cash flows (Jenkinson, Sousa and Stucke (2013)). We control for realization status in our econometric analysis. In terms of industries (Panel E), co-investments occur relatively often within the healthcare sector (32\% of co-investments vs. $22 \%$ of other deals), a characteristic that our sample shares with Fang et al. (2015).

\subsection{GP motives to offer co-investments}

Having identified co-investment, we analyse whether there are particular features of these deals, or the funds from which they are drawn, that explain their status.

We use multivariate probit regressions where the dependent variable is a dummy variable with the value of one if a transaction is a co-investment and zero if it is another deal from the same pool of 464 funds. The first driver of a GP's decision to offer co-invest is likely to be size, relative to the fund. Usually the Limited Partnership Agreement (LPA) will prohibit concentrated risk exposures to single assets (Gompers and Lerner (1996)). By offering relatively large deals to LPs as co-investments, the equity contribution needed from the fund is thereby reduced. Even if the equity required is less than the formal limit imposed by the LPA, GPs may choose to reduce the 
exposure of the fund to any single deal for risk diversification reasons. We proxy relative deal size by dividing a GP's equity investment for each given deal by the total size of equity commitments of the fund through which the deal was made.

GPs may also use co-investments to build or strengthen relationships with LPs. Chung et al. (2012) and Metrick and Yasuda (2010) show that a major bulk of GPs' total lifetime income comes from the ability to raise follow-on funds. Therefore, we include an indicator for whether the deal is before the first closing of the GP's follow-on fund. We source information on fund raising from Capital IQ, Thomson ONE and Pitchbook. It may be that the marginal effect from building relationships through co-investments is stronger for less established GPs. To test this effect, we also include the sequence number of the fund through which the deal was made.

There may also be incentives to offer deals for co-investment if they are outside the fund's typical investment strategy, as these may be viewed as riskier by the GP. Such investment style drift has been observed for mutual funds (Wermers (2012)) and hedge funds (Brown and Goetzmann (2001)). We proxy style drift by including a dummy variable with the value of one if the portfolio company is primarily operating in the least frequently observed one-digit ICB industry category of the respective fund and zero otherwise.

GPs may also feel pressures in the opposite direction: to deploy capital and not offer deals for co-investment. The typical LPA defines an investment period - typically the first 4 or 5 years - during which the capital committed by investors can be called. In addition, follow-on funds cannot generally be raised until a large proportion of the existing fund has been deployed. Therefore, a slow pace of investment may put a GP under pressure to invest the committed capital of the fund. We test this by constructing an investment speed variable. We sum the total invested equity at the time of each deal and divide this by the fund size. We then calculate the difference 
between the investment speed of each fund and the median for funds in the same segment (buyout or VC) and vintage year. For this comparison we use all funds, with cash flow data available, in the Preqin database.

The results of the probit regressions are shown in Table 3. For both buyout and VC deals, we find that relative deal size is consistently significant. Irrespective of whether we include fixed effects for investment year, industry or region, the larger deals in a fund are more likely to be offered for co-investment. The economic effect is, however, quite modest. For example, in the models with a full set of fixed effects, a ten percent increase in relative equity investment by the fund increases the probability of co-investment (on average) by 15 basis points in the case of buyouts and 24 basis points for VC.

For VC funds, none of the other factors we include are statistically significant. In the case of buyout funds, the predicted probability of a co-investment is 2.3 percentage points higher (7.2 vs. 4.9 percent) before a follow-on fund has been raised (holding all other variables at their mean). We also find weak evidence that buyout GPs offer fewer co-investments as they become more established and raise successive funds.

Our finding that the larger deals are more likely to be offered for co-investment is relevant to our analysis of adverse selection. There are various ways of defining selection, from the unconditional (simply comparing deal performance without controlling for any other factors that could influence the decision) to models that have controls for investment year, location, size etc. In this conditional setting, adverse selection would only occur if, for example, controlling for size of deal, the co-investments under-perform. And given that GPs have full discretion over whether to offer smaller deals for co-investment (or keep them within the fund), any adverse selection is 
more likely to show up in these deals. Larger deals may only be possible if co-investors come on board, irrespective of their quality. In the next section we explore these issues.

\section{Is there evidence of adverse, or positive, selection?}

In order to test whether co-investments are a selected sample of the fund investments we focus on gross deal-level returns. As argued earlier, these have the advantage of measuring overall performance of the deals before determining how the gains are shared between the LP and GP (which will be ideosynratic to the fund, and, at the deal level, will be influenced by the overall performance of the fund.) We start, in section 3.1, by presenting the overall distributions of gross returns for co-investments and other fund investments, to get a sense as to whether they differ. In section 3.2 we test more formally for selection by comparing returns within the same fund. This will enable us to control for any GP-specific factors (for example, if particularly skilled or highperforming GPs tend to offer fewer, or more, co-investments). Then in section 3.3 we explore whether the results differ across investor types.

\subsection{Comparing gross return distributions}

In this paper we focus on public market equivalent returns using the approach introduced by Kaplan and Schoar (2005). PMEs have various appealing features, as noted by Sorensen and Jagannathan (2015), but require timed cash-flow data to be implemented. This is the first paper to have this information for all deals in our sample, and so such distributions of returns within buyout and VC funds have not previously been analysed. ${ }^{15}$ Table 4 reports summary statistics. The

\footnotetext{
${ }^{15}$ Fang et al. (2015) have timed cash-flows for their sample of co-investments but not for the remaining investments undertaken by the funds. All PMEs in our study are winsorized at the $99^{\text {th }}$ percentile to account for extreme positive outliers.
} 
(unweighted) mean PME of the buyout co-investments in our sample, presented in Panel A, is 1.76. This is slightly higher than the mean PME of 1.70 in the sample of remaining buyout deals, although the difference is not statistically significant. The median PMEs are also very similar, but are substantially lower than the mean values. This results from the right-skewed distribution of investment returns, illustrated in the histograms of returns presented in Figure $1 .{ }^{16}$

Both deal distributions are characterized by a significant number of poor deals and a few very successful transactions. The highest probability outcome is a PME in the $0-0.5$ range. However, a few deals deliver returns that are 5, 10 or even more than 15 times the return on public markets. We also present the distribution of fund level returns. The median number of investments in our fund sample is 23 , and so the distribution of fund returns displayed in Figure 1 is considerably closer to a Gaussian normal distribution. Those who choose to participate in coinvestments therefore expose themselves to significant deal-level risk.

Capital-weighting the returns has no impact on the buyout co-investment average PME which remains at 1.76 . However, the mean for the other fund deals falls to 1.59 , reflecting the fact that the larger deals not offered for co-investment perform relatively poorly. The difference in the capital-weighted average returns is weakly significant (at the $10 \%$ level). ${ }^{17}$ This result provides an interesting gloss to the finding of Lopez de Silanes, Phalippou and Gottschalg (2015) that larger deals tend to perform poorly. This is true for the majority of the deals in our sample that are not offered for co-investment, but is not a feature of the co-investments.

\footnotetext{
${ }^{16}$ Because of this extreme right-skewness we use PMEs that are winsorized at the $99^{\text {th }}$ percentile throughout the entire paper.

${ }^{17}$ The small difference between the capital-weighted average returns on a deal and fund basis stem from winsorizing the deal sample at the $99^{\text {th }}$ percentile and from the difference between fund size and total invested equity.
} 
For VC, Panel B of Table 4 shows that the mean (median) co-investment PME of 1.25 (0.77) is smaller than the mean PME of $1.37(0.80)$ for the other venture deals. However, this difference reverses on a capital-weighted basis, with average co-investment returns being significantly higher than other fund deals. Figure 1 shows that the risk of $\mathrm{VC}$ deals is, as expected, noticeably higher than buyout deals. More than one third of the transactions yield PMEs in the 0 -0.5 range. However, the incidence of very successful investments appears no higher than for buyouts.

Given the highly non-normal distribution of gross returns at the deal level, the case for investors to engage in co-investment depends on two factors. First, the relative cost advantage of co-investments. And, second, the size of the portfolio of co-investments that the investor builds. Given the highly right-skewed distribution of returns, engaging in single co-investments will, on average, deliver returns that are below the average fund return. Indeed, for our sample of buyout (VC) deals only 35\% (29\%) beat the fund return (Figure 2). Only by committing to a co-investment programme - involving multiple deals - will investors converge on the mean returns, in the absence of investor skill at picking winners. We consider these issues in section 4 .

\subsection{Adverse Selection?}

A simple comparison of return distributions gives the first indication as to whether the samples are selected, but only goes so far. In particular, since it is individual GPs that make the decision regarding which investments to make available for co-investment, it is necessary to control for any GP-specific factors that might influence returns or co-investment choices. We do this, in the remainder of the paper, by measuring deal performance relative to the performance of the remaining investments in the underlying fund. This will give a baseline test of selection. 
Multivariate results using the difference between individual investment and corresponding fund gross PME as dependent variable (winsorized at the $99^{\text {th }}$ percentile) are reported in Table 5. Columns (1) to (4) display results for buyouts, and (5) to (8) for VC. The most parsimonious regressions, (1) and (5), include a dummy variable which takes the value of one if a transaction is a co-investment and zero if it is another deal from the same pool of 464 funds, along with realization status and investment year fixed effects. We control for the latter because much of the variance in returns may be associated with the year in which the investment took place, which could add noise to any comparison of returns. There is no economically or statistically relevant difference in relative gross PME performance in the full cross-section of investments.

To control for other effects on returns, that may potentially blur our view on differences between co-investments and other investments from the same set of funds, we run two further regressions on each of the subsamples. In Models (2) and (6), respectively, we also add region and industry fixed effects to the estimation. The coefficients on co-investments remain unchanged. The same result is obtained when we add the investment-related determinants of the GP's decision to offer a given deal for co-investment (in Table 3) in Models (3) and (7). In both subsamples, we do not find relative investment size to be correlated with relative gross PME. In the buyout sample, investments done before a follow-on fund is closed and those deals hold longer in the portfolio (also see Braun, Jenkinson and Stoff (2017) for this result) perform better relative to the fund. However, most importantly, the coefficients on co-investments in both subsamples do not materially change. ${ }^{18}$

\footnotetext{
${ }^{18}$ Unreported robustness tests using different approaches, among them interaction models, confirm our (non-)findings.
} 
Our measure of relative investment size merges information on investment (by the fund) and fund size, and they might have divergent effects. For instance, if it was the case that small coinvestments performed particularly well, and large co-investments performed particularly badly, the weighted average performance of co-investing could be disappointing. One constraint on testing the impact of deal size is that while we know the fund investment, we do not directly observe the size of the co-investment. However, to test the robustness of our results, we take advantage of nine specialised co-investment funds in our database. These are excluded from our main analysis, but we can match 72 of the deals in these co-investment funds to the main fund investments, and thereby estimate the size of the co-investment relative to the fund investment. On average, the co-investment vehicle's equity investment amounts to around one third (32.3\%) of the GP's fund investment. We use this average ratio to impute a total deal size for all the coinvestments in our sample. In models (4) and (8), we include deal size, as well as the fund size, in our analysis (in place of relative deal size). Neither coefficient is economically or statistically significant. ${ }^{19}$

In summary, based on our large, heterogeneous sample of deals, we find that, across all investors, gross returns from co-investments and other investments from the same funds are very similar. In the next section we explore whether this results holds across investor groups.

\subsection{Do some LPs achieve better co-investment returns?}

In this section we investigate whether some LPs experience significantly better (relative) co-investment returns. It is possible that the relationship that GPs have with particular LPs could influence who is invited to participate in a co-investment, as well as the investment outcome

\footnotetext{
${ }^{19}$ The results are also robust to using imputed deal size from a regression model for the co-investments in our sample.
} 
(Hochberg et al. (2007)). An established relationship between GP and LP could engender trust. This in turn could facilitate the co-investment process, which usually demands quick investment decisions, the sharing of confidential data, as well as effective communication among the involved parties. We proxy for the effect of past relationships by including two binary variables. First, a dummy variable that has a value of one if a GP and an LP had previously done a co-investment together and zero otherwise (previously co-invested). Second, a dummy variable is included with a value of one if the co-investing institutional investor is also invested in the current fund and/or any previous fund managed by this GP, and zero otherwise (fund relationship). In addition to these two variables, we include the natural logarithm of the number of different investors (of whatever type) participating in the respective deal (log syndicate size). This variable acts as an indicator of the exclusivity (or, alternatively, complexity) of a deal.

Previous studies of fund level returns have explored whether particular types of LP achieve better returns, and whether this is associated with skill (Lerner et al. (2007) and Weisbach et al. (2017)). Clearly, however, the skills required for conducting fund due diligence are not the same as deciding whether to co-invest in a deal. We include two variables to proxy for such potential LP direct investment skill. First, we count the number of previous direct investments by an institutional investor at investment date as reported in the Capital IQ deal database. We expect a decreasing marginal effect of such past direct investment experience and so take the logarithm of this count variable (log LP direct investment experience). Second, large LPs are likely to have more human and financial resources to conduct due diligence, and to choose between available opportunities. We proxy for relative size of an institutional investor's PE program by computing the ratio of this LP's number of fund investments and the largest number of fund investments of a single LP in our sample in the year of the co-investment. These are clearly imperfect proxies for 
investor skill/sophistication, but other potentially relevant data (such as educational backgrounds and networks of LPs, years of experience, etc.) are not readily available.

Model (1) in Table 6 shows that these LP characteristics are largely unrelated to the relative performance of buyout co-investments. Apart from syndicate size, none of the LP-related variables is statistically significant in the buyout subsample. The coefficient on syndicate size shows that increasing the number of investors by 50 percent results in a 0.18 lower co-investment PME relative to the fund. In Model (2) we replace the LP variables with investor-type fixed effects. The insignificant F-test indicates that relative co-investment returns do not differ significantly between LP types, although, if anything, endowments (our reference category) seem to perform somewhat worse than other LP types in terms of buyout co-investments. These results remain unchanged (in Model 3) when including both LP-related variables and LP types fixed effects, and (in Model 4) when we add industry and region fixed effects.

The empirical patterns for venture capital co-investments, presented in Models (5) to (8), are broadly similar but differ in two respects. First, the syndicate size variable is not statistically significant. Second, the fund relationship variable is significantly, and positively, related to relative performance in some specifications. PMEs on VC co-investments are about 0.38 higher when the LP is also committed to the corresponding fund (Model 5). However, this coefficient loses significance as we add more controls. In general, we find no consistently significant determinant of $\mathrm{VC}$ co-investment returns.

All in all, therefore, we find little evidence that the relationship between GPs and LPs, or our proxies for the sophistication of LPs, determine the relative outcome of co-investments. Neither do we find that particular types of LP earn significantly higher returns than others. 
The fact that there seems to be no adverse selection at play already suggests that coinvestments should be attractive to investor, if terms on these are indeed more LP-friendly than those offered on fund investments. However, we have shown in section 3.1 that, given the rightskewed return distribution in PE, the average deal, be it a co-investment or not, underperforms the average fund return, and so committing capital via funds enables investors to benefit from the (few) deals with exceptional returns. The relevant question as to whether investors should do coinvestments, and, if yes, with a portfolio of which size, remains unanswered. In the following section we provide more evidence on this issue.

\section{Should investors do co-investments?}

We now switch focus from adverse selection to investor outcomes. We first, in section 4.1, apply the most common co-investment fee structures and reasonable costs for running a co-investment program to our gross cash flows and compute net co-investment returns. Again, these are benchmarked to net fund returns after costs of running a fund program. We then, in section 4.2, use these LP returns to simulate the net returns to co-investment portfolios of reasonable size and benchmark them with fund portfolios.

\subsection{Co-investment economics}

As noted earlier, we are not able to observe the net returns that LPs ultimately realize. However, we can simulate net returns using plausible assumptions about fees and carried interest. Through survey evidence and interviews with industry experts we identified three main fee structures for co-investments, as shown in Figure 3. Paying no management fee and no carried interest is the most common fee scenario (Preqin (2015)). A second scenario assumes a 1\% management fee on net invested capital and $10 \%$ carried interest. We call this the $1 / 10$ scenario. 
Finally, a third scenario assumes no management fee but a $20 \%$ carried interest (the $0 / 20$ scenario). For the second and third scenarios we assume that carried interest is only paid if the return exceeds an $8 \%$ hurdle rate. Carried interest on co-investments is calculated on a deal-by-deal basis as each co-investment represents a stand-alone investment. The fee structures may vary over time and between buyouts and VC, but these three scenarios cover the range observed in practice. ${ }^{20}$

To derive net fund returns we apply the fund economics assumptions outlined in Metrick and Yasuda (2010). LPs are assumed to pay a management fee of $2 \%$ p.a. on committed capital which decreases to $1.5 \%$ p.a. of the invested capital after the investment period. The investment period ends after 60 months or at the time the follow-on fund of the respective GP starts to invest. The fact that management fees in fund structures are paid on committed capital - and not deployed equity capital as for co-investments - is a another driver of the cost discrepancy. In addition, LPs pay $20 \%$ carried interest with a hurdle rate of $8 \%$. We apply an aggregated carried interest calculation for funds (a 'European waterfall'), which represents a more conservative return calculation for the purpose of this paper compared to a deal-by-deal carried interest calculation (known as an 'American waterfall').

Fang et al. (2015) point out that running a co-investment program comes with higher costs for LPs than managing a fund investment portfolio. We simulate the corresponding "net-net" returns that LPs generate when taking into account these internal investment program costs (see Figure 3).

Table 7 displays the results of our net return simulations. In panel A we report that the weighted average net PME for our sample of 246 buyout funds is 1.36, and only marginally lower

\footnotetext{
${ }^{20}$ IRR hurdles are much less prevalent in VC contracts - and so are also less likely to be seen in VC co-investments.
} 
at 1.35 on a net-net basis. In comparison, as shown in panel B, investing in our virtual portfolio of all 365 buyout co-investments would have yielded a capital-weighted PME of 1.76 under the nofee scenario. Paying 1/10 or 0/20 on all buyout co-investments the PMEs would have produced similar net returns: 1.59 and 1.56 respectively. On a net-net basis these returns fall by 0.05 . Therefore, the net returns on buyout co-investments are economically, and statistically, higher than fund net returns for all the plausible fee structures we analyse.

For venture capital, investing into our sample of 218 venture funds would have yielded a net PME of 1.29 (and 1.28 on a net-net basis). This return is lower than the net return on coinvestments, but the difference is only significant for the no-fee structure. However, when we match the co-investment returns to the associated funds we find that the former are significantly higher for all fee structures: average co-investement PME returns (on a net-net basis) beat the remaining fund investments by between 0.39 (for the $0 / 0$ fee structure) and $0.19(0 / 20)$.

This analysis compares all co-investments with all funds. However, contining the approach followed in the previous section, in panel $\mathrm{C}$ we compute the difference between the returns of coinvestments and the PME on the corresponding fund investments. For buyouts, we find that the average co-investment offered without fees out-performs the other deals in the same fund by 0.34 on a net basis (and 0.29 on a net-net basis). The size and significance of the performance differential declines with the $1 / 10$ and, in particular, the $0 / 20$ fee structures, but the earlier pattern of results is confirmed: on a capital-weighted net return basis co-investments out-perform. Comparing co-investment returns to the return on the corresponding fund, the net returns are significantly higher for all assumed fee structures, including the net-net basis. 


\subsection{Diversification}

While we have established that the net returns to investors from co-investments are attractive on average, we also showed in Section 2 that there is a high dispersion of deal-level gross returns, with a significant positive skew. These distributional features imply that investors who participate in co-investments should build portfolios of deals to increase the likelihood of hitting one of the relatively few investments with high returns. We next explore how investor returns compare, in expectation, to fund returns for different size portfolios of co-investments.

We do this by simulating co-investment portfolios of differing sizes. For example, we randomly draw five out of the 365 buyout co-investments in our sample and calculate the capitalweighted average net-net PME of these deals representing the (virtual) return to such a coinvestment program. In comparison, we compute the net-net return obtained by investing into five randomly drawn funds (using fund size as weighting factor). We repeat this procedure 1,000 times (with replacement) and compute average returns for both samples of hypothetical portfolios. We repeat the exercise for portfolios consisting of 10, 20, 30 and 50 investments.

Table 8 displays the results of these simulations, on a net-net basis. Recall that the median return to a single buyout co-investment is 1.16 . If co-investments incur no fees, even portfolios of 5 co-investments have significantly higher median returns at 1.48 . This increases to 1.63 for portfolios of 10 co-investments and 1.65 for 50 co-investments. By this point the median return is close to the overall mean PME of 1.71 . Given that funds are already portfolios of deals, ${ }^{21}$ the benefits of diversification are marginal: the mean and median PMEs are around 1.44. Therefore,

\footnotetext{
${ }^{21}$ The median number of deals in our fund sample is 23 .
} 
under the no-fee scenario, even small portfolios of co-investments perform favourably relative to fund portfolios.

However, fees on co-investments erode much of this advantage. The mean (median) PME for a simulated portfolio of 50 buyout co-investments is 1.54 (1.50) with a 1/10 fee structure, which reduces further to $1.51(1.47)$ for the $0 / 20$ fee structure. The returns on these simulated portfolios of co-investments remain statistically significantly higher than the fund portfolios, but on this netnet basis the economic size of the differential is modest.

Similar results are found, in Panel B, for VC. Given that the distribution of returns is more skewed, portfolios of 20 or more are required before median co-investment returns exceed fund returns, even on a no-fee basis. If fees are charged, median returns on all the simulated coinvestment portfolios are below the returns on portfolios of funds. Mean returns for co-investment portfolios are similar to the fund portfolios once 30 deals or more are included.

Therefore, the attractiveness for LPs of running a co-investment programme depends on the fee advantages offered by GPs. On average, we find a consistent outperformance of buyout coinvestment portfolios, irrespective of different cost structures and portfolio sizes. However, the case for investing in co-investments is substantially weaker if GPs charge fees on these deals. This is particularly true for VC. Given the higher dispersion of deal-level returns for VC, if fees are charged on co-investments only investors willing to build large portfolios of such deals would earn higher returns, in the absence of skill in picking the best deals. 


\section{Comparison with earlier research}

Our findings in this paper can be summarized as follows. First, we find no evidence (using the individual gross returns of each deal) that co-investments suffer from adverse selection. Second, for a range of plausible fee structures, we find that, on average, buyout and $\mathrm{VC}$ co-investments significantly out-perform on a fund-matched, net return basis.

These results are clearly very different to those produced by Fang et al. (2015), who conclude that PE co-investments suffer from adverse selection. However, it is worth re-iterating the differences in our approach. We test for adverse selection using gross deal-level returns, and then separately explore how fee structures impact on investor returns. Fang et al. focus on net returns, since they do not have the underlying gross returns for deals that were not offered for coinvestment. Their dataset comprises net returns for 103 co-investments made by seven LPs, and the net returns on the corresponding funds. Since they do not have cash flow data for the funds they are not able to estimate PMEs, and so focus on IRRs and money multiples. They find mean (median) co-investment IRRs are 9.0 (7.3) percentage points lower, and money multiples are 0.22 (0.33) times lower, than the corresponding fund returns. ${ }^{22}$ These contrary findings on relative performance, and adverse selection, appear puzzling, and in this section we explore various possible explanations, and present some robustness checks on our results.

First, while gross deal-level returns at the fund level are, as we argue, ideal to address the issue of adverse selection by the GP, the LPs who participate in the co-investment obtain their returns from the co-investment vehicle. There could, in principle, be differences between the cash flows received by the fund (which we observe) and the co-investment vehicle (which Fang et al.

\footnotetext{
${ }^{22}$ Their base sample consists of 286 co-investments. However, the analysis on relative returns is based on 103 coinvestments only.
} 
observe). Discussions with experienced LPs suggest that such differences are marginal and mainly reflect the timing of the cash flows. In particular, funds increasingly use credit lines to reduce the number of (and to delay) capital calls that investors receive. Co-investment vehicles do not have credit lines, and so the cash may be called earlier. However, the use of credit lines has only become widespread in the last few years, whereas we only consider co-investments that had occurred by 2010. There may also be deal-related fees that are charged to the co-investment vehicle.

To address this potential concern, we take advantage of the 72 matched deals from the nine co-investment funds in our database (also used to impute co-investment investment size in section 3). For these deals we can observe two separate monthly gross cash flow streams per deal: one for the LP co-investment and another for the GP fund investment. This allows us to evaluate the extent to which the cash flows to the fund and to the co-investment vehicle differ. The correlation in PME returns is very high: 0.982 (IRR: 0.979 , TVPI: 0.984 ). Therefore, there is, in practice, no significant difference between the gross returns accruing to the fund or the co-investment vehicle.

A second potential source of the difference in the results could be the data collection methods. Fang et al. (2015) obtain full co-investment track records directly from seven LPs. Instead of relying on LPs to willingly provide investment and performance data, we construct our sample from the broad transaction database in Capital IQ. Despite academics' frequent use of Capital IQ as a source of private equity transactions (see, e.g. Strömberg (2007), Bernstein et al. (2016)), it is possible that poorly-performing co-investments are under-represented. This would be the case if Capital IQ relies, to some extent, upon voluntary disclosure of information on transactions, and deals with poor returns are kept undisclosed disproportionally more often than 
good deals. ${ }^{23}$ Any such bias would result, in our context, in an overstatement of co-investments' relative performance. ${ }^{24}$

Of course, at the time that a transaction is undertaken the ex post returns are not known. Consequently, this critique relies on transactions only entering into the Capital IQ database with a delay of some years. However, since it is not entirely clear when information is obtained by Capital IQ, it is important that we test, as far as possible, for the existence of any such a bias. To do this we construct an independent sample of co-investments. Any other deal-level dataset would be susceptible to the same critique, and so a comparison based on an alternative commercial database would be inconclusive. Therefore, we mimic the approach taken by Fang et al. (2015) and asked seven LPs, who are active co-investors, to share their full lists of previous co-investments.

We refrained from asking the LPs for performance data on their co-investments, because it substantially decreases the likelihood of obtaining information. All we asked for was the complete list of the co-investment deals they had undertaken. We then use our deal-level performance dataset and go through the same matching process as we did with the list of deals derived from Capital IQ. This results in an alternative sample of 128 co-investments undertaken by these seven LPs. ${ }^{25}$ Table 9 shows that the performance of our two samples is very similar. Our baseline sample of co-investments generated a slightly higher absolute PME but a lower relative PME compared to the alternative sample. Both differences do not differ statistically from zero. We

\footnotetext{
${ }^{23}$ Capital IQ sources information on transactions through regulatory agencies, news aggregators, advisor and company websites, surveys as well as through investors, sellers and target companies. They check whether information is obtained from an accurate and legitimate source.

${ }^{24}$ We thank Josh Lerner for suggesting this possibility.

${ }^{25}$ In total, the seven lists contain 206 co-investments. We are able to match 128 co-investments to our proprietary deal database which results in the alternative co-investment sample. The overlap between the baseline co-investment sample and the alternative co-investment sample consists of ten co-investments.
} 
therefore do not find any evidence that using Capital IQ to identify co-investments introduces a positive sampling bias. In the absence of strictly comparable (gross, deal level cash flow) data, it is difficult to diagnose why Fang et al. found such different results, other than that the LPs from whom they sourced their data had an atypical experience of co-investing.

Finally, there could be a difference in the composition of the data, perhaps due to a concentration of particular types of investor. As noted in the previous section, in our sample buyout co-investments involving endowments perform less well, but represent only $4 \%$ of our LP sample. Similarly, buyout co-investments undertaken by sovereign wealth funds perform relatively poorly in our sample. If the Fang et al. sample includes a higher concentration of such investors and types of deals, then this might explain the difference in our results. However, given the way we collect our data, our results should be representative of the average investor returns.

\section{Conclusions}

Co-investments have become an important feature of the private equity sector. There are obvious advantages for investors, in the form of lower fees and carried interest payments, but previous research by Fang et al. (2015) found adverse selection by GPs, with co-investments underperforming relative to the remaining fund investments. This paper has found very different results using a much larger and more representative sample of co-investment deals. We merge this with the largest dataset of deal-level cash flows to characterise returns relative to public markets.

The main determinant of whether a deal is offered for co-investment is its size (relative to other deals in the fund). This is as expected. All funds have limitations on the proportion that can be invested in individual deals, and GPs aim to diversify the risk of the fund by constructing welldiversified portfolios of deals. Co-investment allows the GP to participate in deals that are large relative to the fund size that might otherwise be viewed as creating too concentrated an exposure. 
We also find evidence that buyout funds are more likely to offer co-investment early in the life of the fund, which could be used to curry favour with investors before inviting them to participate in their next fund.

We find that the gross return distributions at the portfolio company level are similar for coinvestments and the deals that remain entirely within the fund. This is confirmed by econometric tests where we control for other potential drivers of returns, such as the year of investment, industry, which GP ran the deal, fund sequence etc. This like-for-like comparison between coinvestments and other deals finds no significant evidence of selection bias, either positive or negative. Additionally, we consider whether particular types of investor experience better relative returns from their co-investment programmes, perhaps reflecting their experience, size or relationship with the GP. In general we do not find significant differences, in line with recent evidence at the fund level, with the exception that LPs with prior experience of co-investing tend to earn higher returns in $\mathrm{VC}$.

The similarity of gross returns, across the whole sample, results in higher average net returns to investors in co-investments once their lower fees and carried interest are taken into account. The higher cost for investors of running a co-investment programme does not reverse this result. However, we also show, for the first time, the return distribution at the deal level, which is highly non-Gaussian. A significant number of investments perform poorly but these are balanced by a few spectacular successes. Consequently, only 35\% (29\%) of deals within a buyout (VC) fund beat the overall fund return. Investing into private equity funds provides a diversified portfolio of these deal-level returns. In turn, investing in individual co-investments exposes investors to the underlying distribution of deal-level returns. In the absence of remarkable skill, co-investing only makes sense as part of a longer-term strategy. We show, using simulations of different portfolio 
sizes, that relatively small portfolios of 10 buyout deals on average out-perform fund returns, net of fees and costs. For VC the results suggest that larger portfolios, of 20 or more, deals are required, and that significant out-performance (relative to fund investing) is only achieved if the GPs do not charge fees and carried interest on the co-investments. 


\section{References}

Bernstein, Shai, Josh Lerner, Morten Sorensen and Per Strömberg, 2016, Private equity and industry performance, Management Science, 63, 1198-1213.

Braun, Reiner, Tim Jenkinson, and Ingo Stoff, 2017, How persistent is private equity performance? Evidence from deal-level data, Journal of Financial Economics 123, 273-291.

Brown, Stephen J. and William N. Goetzmann, 2001, Hedge funds with style, NBER Working paper 8173, National Bureau of Economic Research.

Chung, Ji-Woong, Berk A. Sensoy, Lea H. Stern, and Michael Weisbach, 2012, Pay for performance from future fund flows: The case of private equity, Review of Financial Studies 25, 3259-3304.

Fang, Lily, Victoria Ivashina, and Josh Lerner, 2015, The disintermediation of financial markets: Direct investing in private equity, Journal of Financial Economics 116, 160-178.

Gompers, Paul and Josh Lerner, 1996, The Use of Covenants: An Empirical Analysis of Venture Partnership Agreements, Journal of Law \& Economics 39, 463-498.

Harris, Robert S., Steven N. Kaplan and Tim Jenkinson, 2016, How do private equity investments perform compared to public equity?, Journal of Investment Management 14, 1-24.

Harris, Robert S., Tim Jenkinson, and Steven N. Kaplan, 2014, Private equity performance: What do we know?, Journal of Finance 69, 1851-1882.

Hochberg, Yael V., Alexander Ljungqvist, and Yang Lu, 2007, Whom you know matters: Venture capital networks and investment performance, Journal of Finance 62, 251-301.

Jenkinson, Tim, Miguel Sousa and Ruediger Stucke, 2013, How fair are the valuations of private equity funds? Working paper available at ssrn.com/abstract $=2229547$.

Kaplan, Steven N. and Per Strömberg, 2009, Leveraged buyouts and private equity, Journal of Economic Perspectives 23, 121-146.

Kaplan, Steven N. and Antionette Schoar, 2005, Private equity performance: Returns, persistence, and capital flows, Journal of Finance 60, 1791-1823.

Lerner, Josh, Antionette Schoar, and Wan Wongsunwai, 2007, Smart institutions, foolish choices: The limited partner performance puzzle, Journal of Finance 62, 731-764.

Metrick, Andrew, and Ayako Yasuda, 2010, The economics of private equity funds, Review of Financial Studies 23, 2303-2341. 
Phalippou, Ludovic, 2009, Beware of venturing into private equity, Journal of Economic Perspectives 23, 147-166.

Phalippou, Ludovic, Christian Rauch, and Marc Umber, 2018, Private equity portfolio company fees, Journal of Financial Economics 129, 559-585.

Preqin (2015), Preqin special report: Private equity co-investment outlook. Available at https://www.preqin.com/docs/reports/Preqin-Special-Report-Private-Equity-CoInvestment-Outlook-November-2015.pdf

Sensoy, Berk A., Yingdi Wang, and Michael S. Weisbach, 2014, Limited partner performance and the maturing of the private equity industry, Journal of Financial Economics 112, 320-343.

Sorensen, Morten and Ravi Jagannathan, 2015, The public market equivalent and private equity performance, Financial Analyst Journal 71, 43-50.

Strömberg, Per, 2007, The new demography of private equity, SIFR Working Paper.

Weisbach, Michael S., Daniel R. Cavagnaro, Berk A. Sensoy, and Yingdi Wang, 2017, Measuring institutional investors' skill from their investments in private equity, Journal of Finance [Forthcoming].

Wermers, Russ, 2012, A matter of style: The causes and consequences of style drift in institutional portfolios, Working paper, University of Maryland at College Park. 


\section{Figure 1: Gross PME distributions of co-investments, other deals, and funds}

This figure plots the distribution of deal ("co-investments" and "others") and fund returns in our sample using the gross public market equivalent (PME) as a return measure. We use the three regional MSCI Performance Indices (Asia, Europe, North America) in local currency as benchmarks for our PME calculations and use the regional index where the GP is located. PMEs are winsorized at the $99^{\text {th }}$ percentage level. Panel A shows three distinct return distributions for the buyout domain: investmentlevel gross PMEs for 365 co-investments and 5,399 other deals from the same funds as well as the gross fund PME distribution for the corresponding 246 buyout funds. Similarly, Panel B shows the deal-level PME return distributions for 651 venture capital co-investments and 7,015 other venture capital deals from the same funds, as well as for the fund-level gross PME of the 218 venture capital funds through which these deals were made.

\section{Panel A: Buyout}

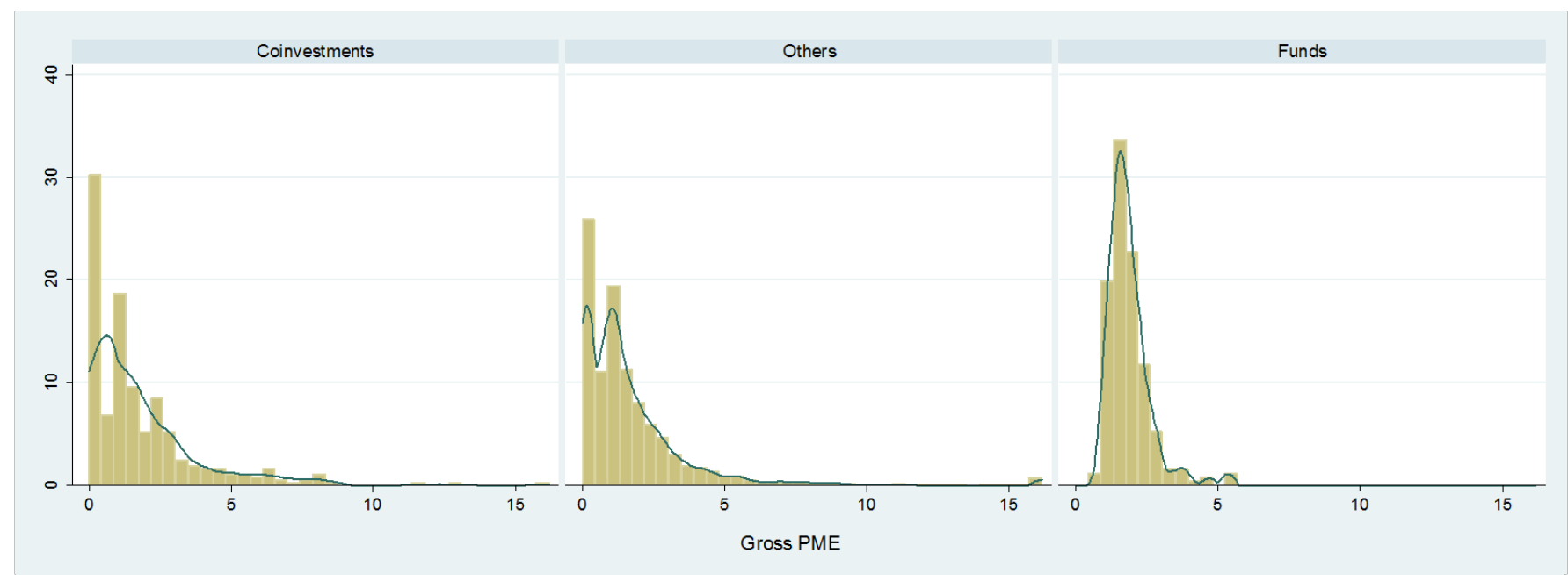

\section{Panel B: Venture Capital}

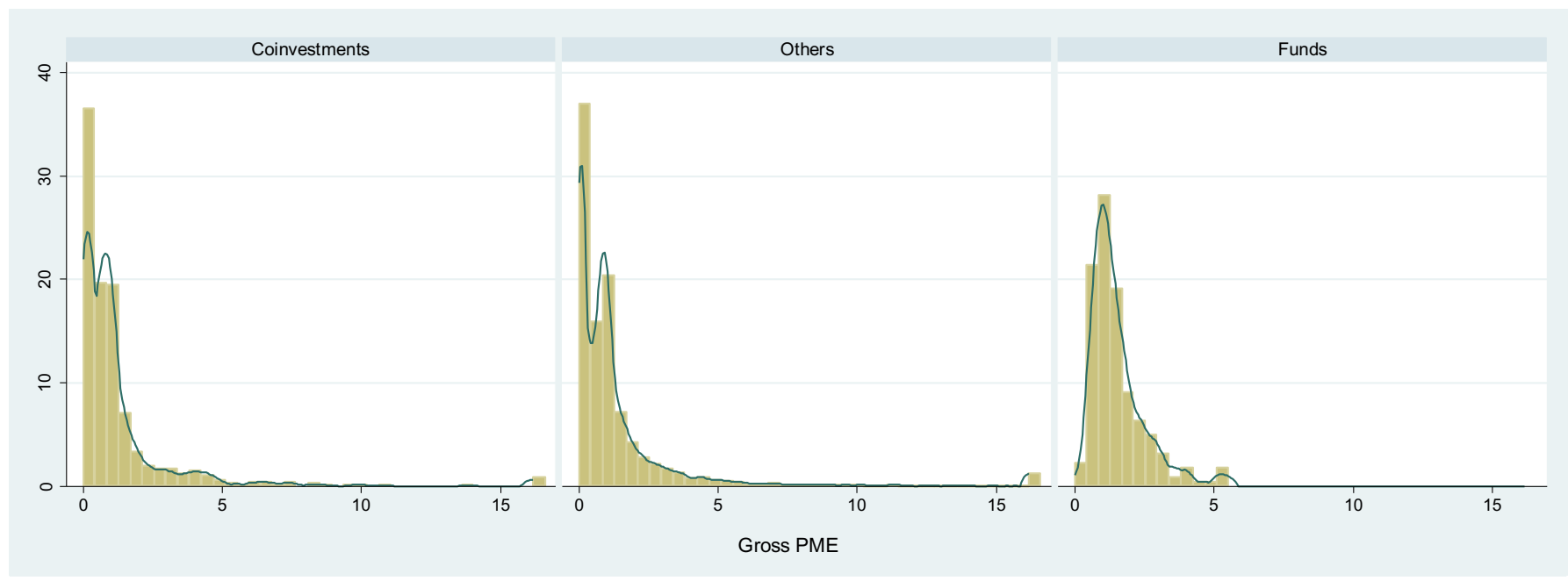


Figure 2: Illustrative gross PME distributions of deals within funds

This figure illustrates the return (gross PME) distributions of deals for our sample of 246 buyout funds (2.1) and 218 VC funds (2.2). We use the three regional MSCI Performance Indices (Asia, Europe, North America) in local currency as benchmarks for our PME calculations and use the regional index where the GP is located. We identify the deal with the highest return within each fund, keeping buyout and venture capital separate, and compute the median gross PME of this distribution. For example, the median top deal gross PME from our 246 buyout funds is 5.7. We repeat this procedure to obtain the median $75^{\text {th }}$ percentile (Q3), 50 ${ }^{\text {th }}$ percentile (median) and $25^{\text {th }}$ percentile (Q1) values. Buyout funds exhibit a median gross PME of 1.70 , whereas only $35 \%$ of deals from these funds generate a gross PME which exceeds their corresponding gross fund PME. The VC funds have a median gross PME of 1.26, and only $29 \%$ of deals from these funds generate a gross PME which exceeds their corresponding gross fund PME.

2.1 Buyout Funds

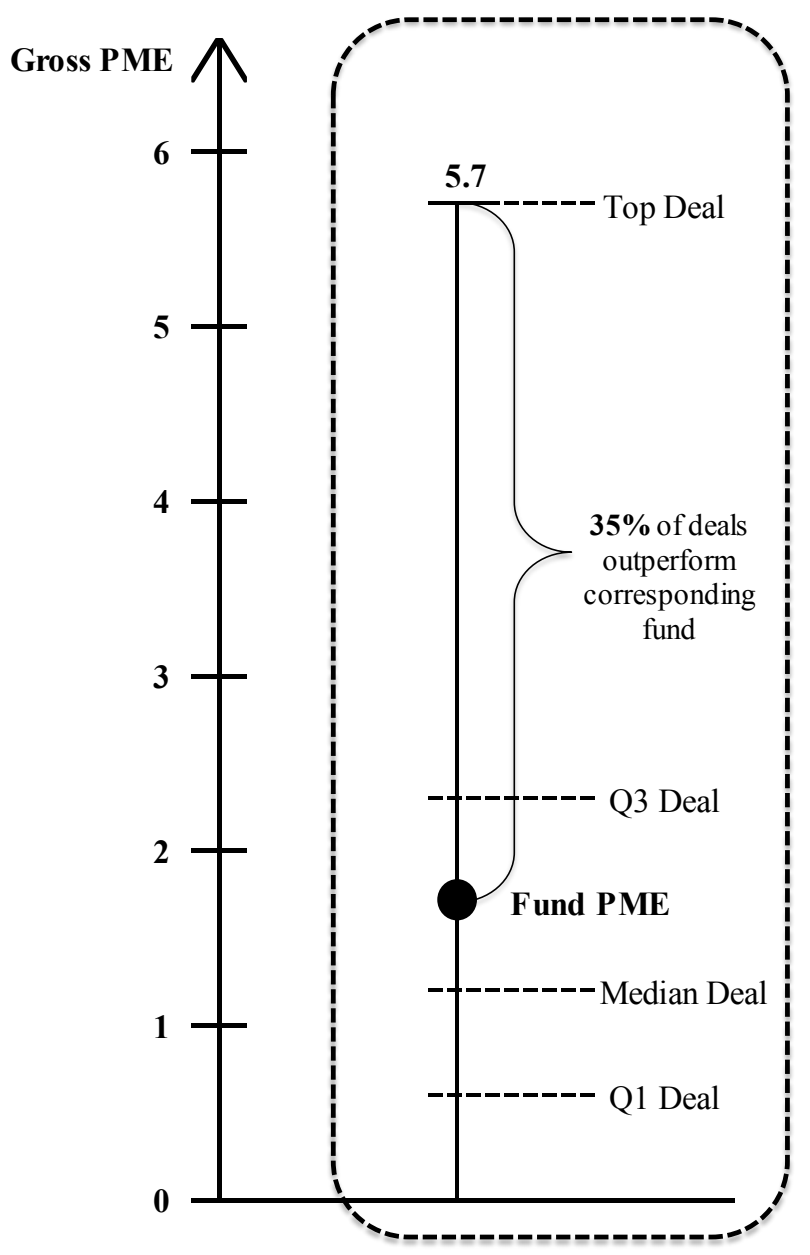

2.2 Venture Capital Funds

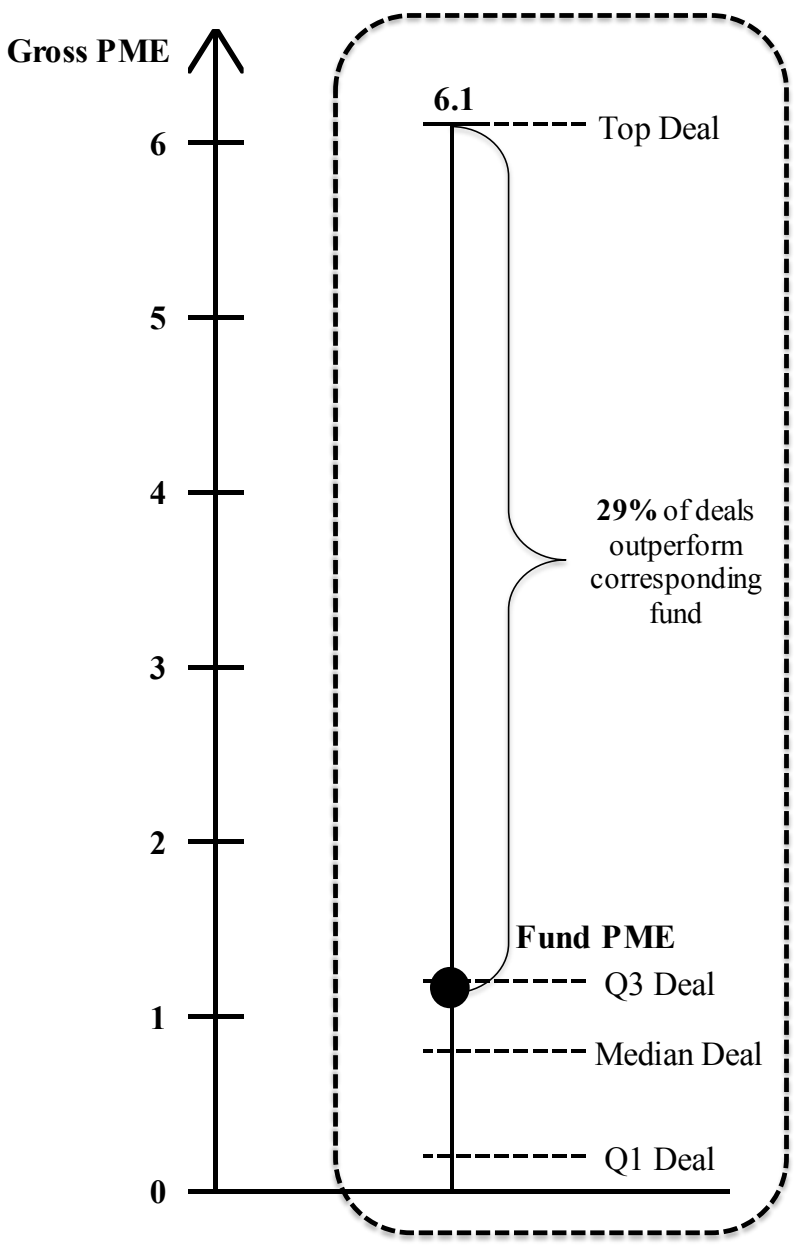




\section{Figure 3: Co-investment fee scenarios}

This figure illustrates the different return levels used in our analyses. It is based on Fang et al. (2015) and is modified for our purpose. Gross returns refer to the cash-flow based returns derived from our proprietary dataset. Net returns refer to the imputed returns we derived by deducting the common fees which General Partners charge. In the case of fund returns, we stick to the fee structure outlined in Metrick and Yasuda (2010). For co-investment returns we use three different fee scenarios which are likely to reflect the range of fees that Limited Partners may be confronted with when doing co-investments (see Preqin (2015)). Finally, net-net returns refer to the imputed returns we derived by deducting cost Limited Partners have to bear in order to run their fund investment programmes and direct investment programmes. In both cases, we stick to the fee set structures outlined in Fang et al. (2015).

\begin{tabular}{|c|c|c|c|}
\hline \multicolumn{4}{|c|}{ Gross Returns (Proprietary dataset) } \\
\hline \multicolumn{2}{|l|}{ - Fund Investment Fees } & \multicolumn{2}{|l|}{ - Co-Investment Fees } \\
\hline \multirow{3}{*}{ as outlined in Metrick and Yasuda (2010) } & Scenario 1 & Scenario 2 & Scenario 3 \\
\hline & No Fees & $1 \%$ Mgmt. Fees & $0 \%$ Mgmt. Fees \\
\hline & INo rees & $10 \%$ Carried Interest & $20 \%$ Carried Interest \\
\hline \multicolumn{4}{|c|}{$=$ Net Returns } \\
\hline \multicolumn{2}{|l|}{ - Costs for Fund Investment programme } & \multicolumn{2}{|c|}{ - Costs for Co-Investment programme } \\
\hline \multirow{2}{*}{\multicolumn{2}{|c|}{$\begin{array}{c}\text { as outlined in Fang et al. (2015) } \\
0.11 \% \text { of commited capital p.a. over five years }\end{array}$}} & \multicolumn{2}{|c|}{ as outlined in Fang et al. (2015) } \\
\hline & & \multicolumn{2}{|c|}{$0.91 \%$ of commited capital p.a. over five years } \\
\hline & Returns & & \\
\hline
\end{tabular}




\section{Table 1: Limited Partner sample}

This table shows descriptive characteristics for 458 institutional investors that directly invested into our sample of 1,016 coinvestments. The data is obtained by merging fund investment information from Capital IQ and Preqin. It displays the average year in which the institutional investor first served as limited partner (LP) in a private equity fund and the average total number of fund investments since then as of November 2015. In Panel A, we differentiate between the two major regional PE markets and all other regions. Panel B splits the sample into eight different LP types. This categorization largely draws on comparable studies, such as Lerner et al. (2007) or Sensoy et al. (2014), but we treat sovereign wealth funds as separate category. Panel C exhibits four quartiles sorted by the total number of historical direct LP investments as proxy for LP direct investing experience.

\begin{tabular}{|lccc}
\hline Panel A: Region categories & Obs. & $\begin{array}{c}\text { Year of first fund } \\
\text { investment }\end{array}$ & $\begin{array}{c}\text { \# of fund } \\
\text { investments }\end{array}$ \\
\hline North America & 279 & 1996 & 55 \\
Europe & 137 & 1997 & 35 \\
RoW & 42 & 1998 & 11 \\
Panel B: LP categories & & & \\
\hline Advisors & 52 & 1998 & 26 \\
Banks / Financial Services & 83 & 1996 & 21 \\
Endowments & 18 & 1994 & 51 \\
Insurance Companies & 46 & 1993 & 87 \\
Investment Firms & 89 & 1997 & 61 \\
Pension Funds & 20 & 1986 & 236 \\
Sovereign Wealth Funds & 4 & 1992 & 133 \\
Others & 146 & 1999 & 13 \\
Panel C: Direct Inv. Experience & & & \\
\hline Most Experienced & 115 & 1995 & 62 \\
2nd & 114 & 1996 & 59 \\
3rd & 115 & 1997 & 18 \\
Least Experienced & 114 & 1998 & $\mathbf{4 5}$ \\
\hline Total & $\mathbf{4 5 8}$ & $\mathbf{1 9 9 6}$ &
\end{tabular}




\section{Table 2: Deal sample}

This table reports median values for 13,430 investments that were made through 464 different funds. The deal sample is split into 1,016 co-investments in which institutional investors invested alongside PE firms and all other 12,414 deals from the same funds. Panel A distinguishes investments by buyout and venture capital funds. In Panel B, we differentiate between the two major regional PE markets and all other regions. Based on investment date, Panel $\mathrm{C}$ assigns each deal into one of five time categories derived from Kaplan and Strömberg (2009). Panel D displays median values by realization status. Finally, Panel E displays the ICB industries in which the portfolio companies are active in. Equity Investment [USDm] refers to the invested equity capital of the General Partner's fund measured in million USD. Fund size [USDm] is the fund size of the related fund measured in million USD. Holding period [years] indicates the difference between this investment date and the exit date or the latest reported valuation (in case of a not yet fully realized transaction) measured in years. Fund age at Inv. date [years] indicates the difference between investment date and the funds first cashflow measured in years.

\begin{tabular}{|c|c|c|c|c|c|c|c|c|c|c|}
\hline \multirow[b]{2}{*}{ Panel A: Type of investment } & \multicolumn{2}{|c|}{ Obs. } & \multicolumn{2}{|c|}{$\begin{array}{c}\text { Equity } \\
\text { Investment }\end{array}$} & \multicolumn{2}{|c|}{ Fund size } & \multicolumn{2}{|c|}{$\begin{array}{c}\text { Holding } \\
\text { Period }\end{array}$} & \multicolumn{2}{|c|}{$\begin{array}{l}\text { Fund age at } \\
\text { Inv. Date }\end{array}$} \\
\hline & Co-Inv & Other & Co-Inv & Other & Co-Inv & Other & Co-Inv & Other & Co-Inv & Other \\
\hline Buyout & 365 & 5,399 & 22.9 & 21.2 & 831.4 & 1193.1 & 3.8 & 4.0 & 1.4 & 1.8 \\
\hline Venture Capital & 651 & 7,015 & 5.8 & 4.9 & 270.0 & 304.0 & 3.5 & 3.5 & 1.2 & 1.3 \\
\hline \multicolumn{11}{|l|}{ Panel B: Region categories } \\
\hline North America & 709 & 7,617 & 8.0 & 7.6 & 400.0 & 447.9 & 3.7 & 3.8 & 1.2 & 1.4 \\
\hline Europe & 243 & 3,447 & 9.1 & 10.0 & 306.0 & 526.5 & 3.9 & 4.0 & 1.5 & 1.6 \\
\hline RoW & 41 & 757 & 18.0 & 11.4 & 800.0 & 1100.0 & 2.6 & 2.6 & 1.5 & 1.7 \\
\hline Unreported & 23 & 593 & 8.2 & 5.3 & 244.0 & 579.0 & 4.1 & 2.9 & 1.7 & 1.8 \\
\hline \multicolumn{11}{|l|}{ Panel C: Time categories } \\
\hline 1981-1989 & 21 & 597 & 1.4 & 1.2 & 69.0 & 92.5 & 6.3 & 6.0 & 1.4 & 1.3 \\
\hline $1990-1994$ & 50 & 913 & 2.5 & 3.2 & 175.5 & 199.0 & 4.8 & 4.7 & 1.6 & 1.8 \\
\hline 1995-1999 & 271 & 3,367 & 6.2 & 7.1 & 224.0 & 389.6 & 4.3 & 4.8 & 1.0 & 1.1 \\
\hline 2000-2004 & 472 & 4,937 & 8.9 & 9.5 & 414.0 & 505.0 & 4.0 & 3.9 & 1.3 & 1.6 \\
\hline $2005-2010$ & 202 & 2,600 & 19.8 & 20.0 & 808.0 & 1138.0 & 1.5 & 1.7 & 1.7 & 1.9 \\
\hline \multicolumn{11}{|l|}{ Panel D: Realization status } \\
\hline Fully Realized & 549 & 7,335 & 7.3 & 6.8 & 333.0 & 447.9 & 3.8 & 3.8 & 1.2 & 1.4 \\
\hline Partially Realized & 136 & 1,855 & 16.1 & 21.6 & 454.0 & 999.2 & 4.8 & 4.8 & 1.3 & 1.5 \\
\hline Unrealized & 331 & 3,224 & 8.2 & 7.8 & 393.3 & 450.4 & 2.7 & 1.7 & 1.5 & 1.7 \\
\hline \multicolumn{11}{|c|}{ Panel E: Industry categories (ICB Codes) } \\
\hline Oil \& Gas (0000s) & 2 & 79 & 11.6 & 30.0 & 7603.5 & 1200.0 & 3.5 & 3.7 & 1.2 & 1.3 \\
\hline Basic Materials (1000s) & 9 & 133 & 31.5 & 43.7 & 1773.4 & 2022.0 & 2.7 & 4.1 & 0.8 & 1.5 \\
\hline Industrials (2000s) & 87 & 1,435 & 12.7 & 12.7 & 417.0 & 643.1 & 3.8 & 4.0 & 0.8 & 1.5 \\
\hline Consumer Goods (3000s) & 41 & 840 & 54.5 & 21.0 & 1318.0 & 1040.0 & 4.0 & 3.8 & 1.0 & 1.6 \\
\hline Health Care (4000s) & 328 & 2,688 & 5.7 & 5.7 & 224.0 & 304.0 & 3.8 & 4.0 & 1.3 & 1.4 \\
\hline Consumer Services (5000s) & 71 & 1,183 & 17.8 & 17.1 & 612.3 & 850.0 & 3.8 & 3.7 & 1.5 & 1.7 \\
\hline Telecommunications (6000s) & 111 & 1,114 & 10.9 & 8.2 & 428.0 & 450.4 & 3.0 & 3.3 & 1.2 & 1.2 \\
\hline Utilities (7000s) & 12 & 140 & 20.2 & 10.1 & 909.0 & 967.5 & 3.5 & 2.5 & 1.3 & 1.5 \\
\hline Financials (8000s) & 39 & 382 & 34.1 & 20.0 & 992.5 & 992.5 & 3.8 & 3.5 & 1.3 & 1.8 \\
\hline Technology (9000s) & 280 & 3,754 & 7.0 & 6.6 & 363.0 & 423.0 & 3.6 & 3.5 & 1.2 & 1.5 \\
\hline Unreported & 36 & 666 & 16.4 & 5.5 & 412.4 & 808.0 & 3.1 & 3.3 & 1.7 & 2.0 \\
\hline Total & 1,016 & 12,414 & 8.3 & 8.3 & 393.3 & 500.0 & 3.7 & 3.7 & 1.3 & 1.5 \\
\hline
\end{tabular}




\section{Table 3: General Partners' motives to syndicate with Limited Partners}

This table reports probit regressions where the dependent variable is one for co-investments and zero otherwise. Regressions (1) to (3) include buyout deals only while regressions (4) to (6) focus venture capital deals. The independent variable Log Relative Deal Size is the natural logarithm of the invested equity by the related fund divided by the total equity invested by the same fund. Interim Investment Speed is the difference between total invested equity divided by total committments of the fund through which the respective deal was done at investment date and the median across peer funds (same vintage year) using Preqin's fund cashflow data to compute benchmarks. Pre Follow-on Fund is a dummy variable adopting a value of one if a deal was done before the first closing of the follow-on fund and zero otherwise. Fund Generation represents the fund sequence of the fund through which the respective deal was made within a GP's fund programme. Industry Style Drift is a dummy adopting the value of one if the portfolio company is primarily operating in the least frequently observed one-digit ICB industry category of the respective fund. Models (2) and (5) contain investment year fixed effects. In models (3) and (6) we also add ICB industry and major regional PE market region fixed effects to the regressions. Standard errors are shown in parentheses.*, ** and *** denote statistical significance at the $10 \%, 5 \%$ and $1 \%$ level, respectively.

\section{Co-Investment Dummy}

\section{VARIABLES:}

Log Relative Deal Size

Interim Investment Speed

Pre Follow-on Fund

Fund Generation

Industry Style Drift

Investment Year FE

Industry FE

Region FE

Constant

Observations
Buyout

(2)

(1)

\begin{tabular}{ccc}
\hline $0.092 * * *$ & $0.114 * * *$ & $0.120 * * *$ \\
$(0.025)$ & $(0.026)$ & $(0.027)$ \\
0.041 & 0.043 & 0.033 \\
$(0.048)$ & $(0.051)$ & $(0.051)$
\end{tabular}

\section{(4)}

\begin{tabular}{ccc}
\hline $0.180 * * *$ & $0.166 * * *$ & $0.153 * * *$ \\
$(0.021)$ & $(0.022)$ & $(0.022)$ \\
0.058 & 0.052 & 0.061 \\
$(0.039)$ & $(0.041)$ & $(0.041)$ \\
& & \\
-0.032 & -0.007 & -0.027 \\
$(0.065)$ & $(0.066)$ & $(0.067)$ \\
0.003 & -0.006 & -0.007 \\
$(0.008)$ & $(0.009)$ & $(0.009)$ \\
& & \\
-0.016 & -0.034 & 0.113 \\
$(0.098)$ & $(0.099)$ & $(0.106)$
\end{tabular}

Venture Capital

$\begin{array}{cccccc}0.220 * * & 0.200 * * & 0.202 * * & -0.032 & -0.007 & -0.027 \\ (0.092) & (0.094) & (0.095) & (0.065) & (0.066) & (0.067) \\ -0.022 * & -0.018 & -0.025^{*} & 0.003 & -0.006 & -0.007 \\ (0.012) & (0.014) & (0.014) & (0.008) & (0.009) & (0.009) \\ & & & & & \\ 0.068 & 0.072 & -0.005 & -0.016 & -0.034 & 0.113 \\ (0.097) & (0.098) & (0.104) & (0.098) & (0.099) & (0.106) \\ \text { No } & \text { Yes } & \text { Yes } & \text { No } & \text { Yes } & \text { Yes } \\ \text { No } & \text { No } & \text { Yes } & \text { No } & \text { No } & \text { Yes } \\ \text { No } & \text { No } & \text { Yes } & \text { No } & \text { No } & \text { Yes }\end{array}$

\begin{tabular}{cccccc}
$-1.285 * * *$ & $-1.784 * * *$ & $-1.918 * * *$ & $-0.627 * * *$ & $-1.399 * * *$ & $-1.420 * * *$ \\
$(0.129)$ & $(0.429)$ & $(0.537)$ & $(0.107)$ & $(0.442)$ & $(0.483)$ \\
4,616 & 4,552 & 4,552 & 7,254 & 7,138 & 7,124 \\
\hline
\end{tabular}




\section{Table 4: Gross PMEs of co-investments, fund investments, and funds}

This table shows gross PME return distributions of our buyout (Panel A) and venture capital (Panel B) samples. For each panel, distributional features are displayed at deal and fund level. We use the three regional MSCI Performance Indices (Asia, Europe, North America) in local currency as benchmarks for our PME calculations and use the regional index where the GP is located. Both panels provide unweighted figures on the mean, median, lower quartile $\left(25^{\text {th }}\right)$, upper quartile $\left(75^{\text {th }}\right)$ and $99^{\text {th }}$ percentile gross PME. Furthermore, the corresponding standard deviation, skewness and kurtosis of the gross PME distributions are shown. Additionally, the capital-weighted mean PME is displayed. Deal PMEs are capital-weighted by the invested equity measured in USD, whereas fund PMEs are capital-weighted by the fund size measured in USD. In both panels we report statistical significance tests on the equality of gross PME distributions of co-investments and other deals from the same funds where no LP co-invested in the respective deal. We perform a two-sample t-test for the unweighted mean (1), a Wilcoxon ranksum test for the unweighted median (2) and a two-sample Kolmogorov-Smirnov test for the unweighted distributions (3). For the weighted mean we report statistical significance for the null hypothesis that the weighted mean of co-investments is equal to the weighted mean of the other deals (4). *,** and *** denote statistical significance at the $10 \%, 5 \%$ and $1 \%$ level, respectively.

\section{Panel A: Buyout}

\begin{tabular}{|c|c|c|c|c|c|c|c|c|c|c|}
\hline \multirow[b]{3}{*}{ A.1 Deals } & \multirow{3}{*}{$\begin{array}{c}\text { Obs. } \\
5,764\end{array}$} & \multicolumn{8}{|c|}{ Gross PME (unweighted) } & \multirow{2}{*}{$\begin{array}{c}\text { Gross PME (weighted) } \\
\text { Mean } \\
\end{array}$} \\
\hline & & Mean & 25th & Median & 75th & 99th & SD & Skewnes & Kurtosis & \\
\hline & & 1.70 & 0.40 & 1.14 & 2.17 & 11.34 & 2.15 & 3.44 & 19.86 & 1.60 \\
\hline Co-Investments & 365 & 1.76 & 0.26 & 1.16 & 2.45 & 8.43 & 2.10 & 2.50 & 12.45 & 1.76 \\
\hline Others & 5,399 & 1.70 & 0.41 & 1.13 & 2.15 & 11.35 & 2.15 & 3.50 & 20.32 & 1.59 \\
\hline Significance tests & \multicolumn{5}{|c|}{$-0.55 / 0.59^{(1)}$} & & \multicolumn{3}{|c|}{$0.051 / 0.307^{(3)}$} & $1.89 / 0.059^{*}(4)$ \\
\hline A.2 Funds & 246 & 1.86 & 1.39 & 1.70 & 2.11 & 5.37 & 0.75 & 2.04 & 9.06 & 1.59 \\
\hline
\end{tabular}

\section{Panel B: Venture Capital}

Panel B: Venture Capital

\begin{tabular}{|c|c|c|c|c|c|c|c|c|c|c|}
\hline & \multirow[b]{2}{*}{ Obs. } & \multicolumn{8}{|c|}{ Gross PME (unweighted) } & \multirow{2}{*}{$\begin{array}{c}\text { Gross PME (weighted) } \\
\text { Mean }\end{array}$} \\
\hline & & Mean & 25th & Median & 75th & 99th & SD & Skewness & Kurtosis & \\
\hline B.1 Deals & 7,666 & 1.36 & 0.10 & 0.80 & 1.35 & 16.16 & 2.40 & 4.12 & 22.87 & 1.35 \\
\hline Co-Investments & 651 & 1.25 & 0.15 & 0.77 & 1.24 & 13.84 & 2.13 & 4.39 & 27.10 & 1.55 \\
\hline Others & 7,015 & 1.37 & 0.09 & 0.80 & 1.37 & 16.16 & 2.42 & 4.10 & 22.52 & 1.33 \\
\hline Significance tests & \multicolumn{3}{|c|}{$1.20 / 0.23^{(1)}$} & $46 / 0.65$ & & & \multicolumn{3}{|c|}{$0.054 / 0.055^{(3)}$} & $2.73 / 0.007 * * *(4)$ \\
\hline B.2 Funds & 218 & 1.53 & 0.86 & 1.26 & 1.88 & 5.37 & 0.95 & 1.72 & 6.43 & 1.49 \\
\hline
\end{tabular}




\section{Table 5: Do coinvestments perform better or worse than other fund investments?}

This table presents the results from deal level OLS regressions using gross deal PME minus corresponding fund PME as the dependent variable in all regression models, separating our buyout (Regressions 1 to 4 ) from the venture capital sample (5 to 8). We resort on the three regional MSCI Performance Indices (Asia, Europe, North America) in local currency as benchmarks for our PME calculations and use the regional index where the GP is located. PMEs are winsorized at the $99^{\text {th }}$ percentage level. The independent variable Co-investment is a dummy variable which is one in case the respective deal contains a co-investment by an institutional investor and zero if otherwise. Log Relative Deal Size is the natural logarithm of the invested equity by the related fund divided by the total equity invested by the same fund. Log Deal Size is the natural logarithm of the invested equity using imputed values for all co-investments. Log Fund Size is the natural logarithm of the total equity invested by a fund. Pre Followon Fund is a dummy variable which is one if a deal was done before the first closing of the follow-on fund and zero otherwise. Fund Generation represents the fund sequence of the fund through which the respective deal was made within a GP's fund programme. Holding Period indicates the differences between the investment date and the exit date or the latest reported valuation (in case of a not yet fully realized transaction). All models include realization status fixed effects. In addition, models (2) to (4) and (5) to (8) contain investment year fixed effects. Model (3) and (4) as well as (7) and (8) also include ICB industry fixed effects and major regional PE market region fixed effects. Standard errors are adjusted for serial correlation as well as heteroscedasticity and are shown in parentheses. ${ }^{*}, * *$ and $* * *$ denote statistical significance at the $10 \%, 5 \%$ and $1 \%$ level, respectively.

\begin{tabular}{|c|c|c|c|c|c|c|c|c|}
\hline \multirow[b]{3}{*}{ VARIABLES: } & \multicolumn{8}{|c|}{ Deal PME minus Fund PME } \\
\hline & \multicolumn{4}{|c|}{ Buyout } & \multicolumn{4}{|c|}{ Venture Capital } \\
\hline & (1) & $(2)$ & (3) & (4) & (5) & (6) & (7) & (8) \\
\hline Co-Investment & $\begin{array}{c}0.033 \\
(0.110)\end{array}$ & $\begin{array}{c}0.032 \\
(0.110)\end{array}$ & $\begin{array}{c}0.038 \\
(0.112)\end{array}$ & $\begin{array}{l}-0.021 \\
(0.119)\end{array}$ & $\begin{array}{c}0.029 \\
(0.086)\end{array}$ & $\begin{array}{c}0.007 \\
(0.087)\end{array}$ & $\begin{array}{c}0.009 \\
(0.088)\end{array}$ & $\begin{array}{l}-0.032 \\
(0.095)\end{array}$ \\
\hline Log Relative Deal Size & & & $\begin{array}{l}-0.024 \\
(0.033)\end{array}$ & & & & $\begin{array}{l}-0.031 \\
(0.038)\end{array}$ & \\
\hline Log Deal Size & & & & $\begin{array}{c}-0.044 \\
(0.035)\end{array}$ & & & & $\begin{array}{l}-0.027 \\
(0.032)\end{array}$ \\
\hline Log Fund Size & & & & $\begin{array}{l}-0.000 \\
(0.033)\end{array}$ & & & & $\begin{array}{l}-0.028 \\
(0.041)\end{array}$ \\
\hline Pre Follow-on Fund & & & $\begin{array}{c}0.184 * * \\
(0.081)\end{array}$ & $\begin{array}{c}0.202 * * \\
(0.080)\end{array}$ & & & $\begin{array}{c}0.064 \\
(0.081)\end{array}$ & $\begin{array}{c}0.083 \\
(0.085)\end{array}$ \\
\hline Holding Period & & & $\begin{array}{l}0.022^{*} \\
(0.012)\end{array}$ & $\begin{array}{c}0.025^{* *} \\
(0.012)\end{array}$ & & & $\begin{array}{c}0.016 \\
(0.012)\end{array}$ & $\begin{array}{c}0.019 \\
(0.013)\end{array}$ \\
\hline Investment Year FE & Yes & Yes & Yes & Yes & Yes & Yes & Yes & Yes \\
\hline Industry FE & No & Yes & Yes & Yes & No & Yes & Yes & Yes \\
\hline Region FE & No & Yes & Yes & Yes & No & Yes & Yes & Yes \\
\hline Realization Status FE & Yes & Yes & Yes & Yes & Yes & Yes & Yes & Yes \\
\hline Constant & $\begin{array}{c}1.146 \\
(1.910)\end{array}$ & $\begin{array}{c}1.551 \\
(1.969)\end{array}$ & $\begin{array}{c}1.051 \\
(1.948)\end{array}$ & $\begin{array}{c}1.087 \\
(1.947)\end{array}$ & $\begin{array}{c}-1.222^{* * *} \\
(0.271)\end{array}$ & $\begin{array}{c}-2.069^{* * *} \\
(0.466)\end{array}$ & $\begin{array}{c}-2.394 * * * \\
(0.514)\end{array}$ & $\begin{array}{c}-2.248^{* * *} \\
(0.504)\end{array}$ \\
\hline Observations & 5,764 & 5,764 & 5,590 & 5,590 & 7,666 & 7,666 & 7,414 & 7,414 \\
\hline R-squared & 0.024 & 0.029 & 0.031 & 0.031 & 0.023 & 0.028 & 0.028 & 0.028 \\
\hline
\end{tabular}

Standard errors in parentheses 


\section{Table 6: Co-investment performance across LPs}

This table presents the results from deal level OLS regressions. The difference between the co-investment PME (no fee scenario) and the corresponding net fund PME is the dependent variable in all regression models. We resort on the three regional MSCI Performance Indices (Asia, Europe, North America) in local currency as benchmarks for our PME calculations and use the regional index where the GP is located. PME differences are winsorized at the 99th percentage level. Models (1) to (4) include buyout deals while models (5) to (8) contain venture capital deals only. Previously co-invested is a dummy variable which is one if the respective LP has already co-invested with the same GP before the current co-investment (as indicated by S\&P Capital IQ's deal database) and zero otherwise. Fund Relationship is a dummy variable adopting the value of one if the LP is invested in the current fund of the GP (the one where the co-investment comes from) and/or a previous fund of the same GP. The information regarding LPs' fund investments comes from Preqin and S\&P Capital IQ. Log LP direct inv experience is the natural logarithm of the sum of a LP's past direct PE investments as of the date of the co-investment (as indicated by S\&P Capital IQ). Relative LP Size is the ratio of a LPs number of fund investments and the largest number of a single LP's fund investments in our sample in the year of the respective co-investment. Log Syndicate Size is the natural logarithm of the number of different investors participating in the respective deal where the LP co-invested. All models include realization status fixed effects. In addition, models (2) to (4) and (6) to (8) contain LP type fixed effects using eight categories. Model (4) and (8) also include ICB industry fixed effects and major regional PE market region fixed effects. F-statistics from testing joint significance of LP Type fixed effects in regressions (2) to (4) and (6) to (8) are shown at the very bottom of the table. Standard errors are shown in parentheses. $^{*}, * *$ and $* * *$ denote statistical significance at the $10 \%, 5 \%$ and $1 \%$ level, respectively.

\begin{tabular}{|c|c|c|c|c|c|c|c|c|}
\hline \multirow{3}{*}{ VARIABLES: } & \multicolumn{8}{|c|}{ Co-Inv. PME minus Fund PME } \\
\hline & \multicolumn{4}{|c|}{ Buyout } & \multicolumn{4}{|c|}{ Venture Capital } \\
\hline & (1) & (2) & (3) & (4) & (5) & (6) & (7) & (8) \\
\hline Previously co-invested & $\begin{array}{c}0.221 \\
(0.336)\end{array}$ & & $\begin{array}{c}0.204 \\
(0.335)\end{array}$ & $\begin{array}{c}0.218 \\
(0.349)\end{array}$ & $\begin{array}{l}-0.161 \\
(0.211)\end{array}$ & & $\begin{array}{l}-0.155 \\
(0.213)\end{array}$ & $\begin{array}{l}-0.155 \\
(0.211)\end{array}$ \\
\hline Fund Relationship & $\begin{array}{l}-0.225 \\
(0.228)\end{array}$ & & $\begin{array}{l}-0.293 \\
(0.235)\end{array}$ & $\begin{array}{l}-0.291 \\
(0.236)\end{array}$ & $\begin{array}{c}0.378 * * \\
(0.192)\end{array}$ & & $\begin{array}{l}0.383 * \\
(0.200)\end{array}$ & $\begin{array}{c}0.328 \\
(0.203)\end{array}$ \\
\hline Log LP direct inv experience & $\begin{array}{l}-0.013 \\
(0.059)\end{array}$ & & $\begin{array}{c}-0.014 \\
(0.059)\end{array}$ & $\begin{array}{l}-0.010 \\
(0.060)\end{array}$ & $\begin{array}{c}0.082 \\
(0.055)\end{array}$ & & $\begin{array}{l}0.096^{*} \\
(0.057)\end{array}$ & $\begin{array}{c}0.094 \\
(0.058)\end{array}$ \\
\hline Relative LP Size & $\begin{array}{l}-0.563 \\
(0.501)\end{array}$ & & $\begin{array}{l}-0.703 \\
(0.565)\end{array}$ & $\begin{array}{l}-0.593 \\
(0.610)\end{array}$ & $\begin{array}{l}-0.407 \\
(0.447)\end{array}$ & & $\begin{array}{l}-0.383 \\
(0.485)\end{array}$ & $\begin{array}{l}-0.271 \\
(0.486)\end{array}$ \\
\hline Log Syndicate Size & $\begin{array}{c}-0.406^{* *} \\
(0.172)\end{array}$ & & $\begin{array}{c}-0.414^{* *} \\
(0.181)\end{array}$ & $\begin{array}{c}-0.391 * \\
(0.201)\end{array}$ & $\begin{array}{l}-0.061 \\
(0.149)\end{array}$ & & $\begin{array}{l}-0.063 \\
(0.152)\end{array}$ & $\begin{array}{c}-0.086 \\
(0.156)\end{array}$ \\
\hline \multicolumn{9}{|l|}{$\underline{\text { Ref.: Endowments }}$} \\
\hline Advisors & & $\begin{array}{c}1.038 \\
(0.653)\end{array}$ & $\begin{array}{c}0.980 \\
(0.672)\end{array}$ & $\begin{array}{c}0.851 \\
(0.676)\end{array}$ & & $\begin{array}{c}0.218 \\
(0.519)\end{array}$ & $\begin{array}{c}0.307 \\
(0.523)\end{array}$ & $\begin{array}{c}0.368 \\
(0.515)\end{array}$ \\
\hline Banks / Financial Services & & $\begin{array}{c}0.484 \\
(0.429)\end{array}$ & $\begin{array}{c}0.273 \\
(0.445)\end{array}$ & $\begin{array}{c}0.195 \\
(0.437)\end{array}$ & & $\begin{array}{l}-0.031 \\
(0.263)\end{array}$ & $\begin{array}{c}0.030 \\
(0.279)\end{array}$ & $\begin{array}{c}0.109 \\
(0.289)\end{array}$ \\
\hline Insurance Companies & & $\begin{array}{c}0.617 \\
(0.513)\end{array}$ & $\begin{array}{c}0.495 \\
(0.517)\end{array}$ & $\begin{array}{c}0.404 \\
(0.503)\end{array}$ & & $\begin{array}{l}-0.056 \\
(0.337)\end{array}$ & $\begin{array}{c}0.028 \\
(0.357)\end{array}$ & $\begin{array}{c}0.053 \\
(0.363)\end{array}$ \\
\hline Investment Firms & & $\begin{array}{c}0.524 \\
(0.408)\end{array}$ & $\begin{array}{c}0.544 \\
(0.431)\end{array}$ & $\begin{array}{c}0.524 \\
(0.424)\end{array}$ & & $\begin{array}{c}0.250 \\
(0.263)\end{array}$ & $\begin{array}{c}0.272 \\
(0.268)\end{array}$ & $\begin{array}{c}0.272 \\
(0.277)\end{array}$ \\
\hline Pension Funds & & $\begin{array}{c}1.068 * * \\
(0.529)\end{array}$ & $\begin{array}{c}1.102 * * \\
(0.547)\end{array}$ & $\begin{array}{c}1.059^{* *} \\
(0.536)\end{array}$ & & $\begin{array}{c}0.171 \\
(0.483)\end{array}$ & $\begin{array}{c}0.242 \\
(0.540)\end{array}$ & $\begin{array}{c}0.307 \\
(0.567)\end{array}$ \\
\hline Sovereign Wealth Funds & & $\begin{array}{c}0.620 \\
(0.447)\end{array}$ & $\begin{array}{c}0.985 \\
(0.711)\end{array}$ & $\begin{array}{c}0.828 \\
(0.634)\end{array}$ & & $\begin{array}{c}1.024 \\
(1.115)\end{array}$ & $\begin{array}{c}1.387 \\
(1.128)\end{array}$ & $\begin{array}{c}1.546 \\
(1.198)\end{array}$ \\
\hline Others & & $\begin{array}{c}0.324 \\
(0.433)\end{array}$ & $\begin{array}{c}0.277 \\
(0.443)\end{array}$ & $\begin{array}{c}0.348 \\
(0.440)\end{array}$ & & $\begin{array}{c}0.318 \\
(0.280)\end{array}$ & $\begin{array}{c}0.413 \\
(0.295)\end{array}$ & $\begin{array}{c}0.446 \\
(0.293)\end{array}$ \\
\hline $\begin{array}{l}\text { Realization Status FE } \\
\text { Industry FE } \\
\text { Region FE }\end{array}$ & $\begin{array}{l}\text { Yes } \\
\text { No } \\
\text { No }\end{array}$ & $\begin{array}{l}\text { Yes } \\
\text { No } \\
\text { No }\end{array}$ & $\begin{array}{l}\text { Yes } \\
\text { No } \\
\text { No }\end{array}$ & $\begin{array}{l}\text { Yes } \\
\text { Yes } \\
\text { Yes }\end{array}$ & $\begin{array}{l}\text { Yes } \\
\text { No } \\
\text { No }\end{array}$ & $\begin{array}{l}\text { Yes } \\
\text { No } \\
\text { No }\end{array}$ & $\begin{array}{l}\text { Yes } \\
\text { No } \\
\text { No }\end{array}$ & $\begin{array}{l}\text { Yes } \\
\text { Yes } \\
\text { Yes }\end{array}$ \\
\hline Constant & $\begin{array}{c}0.219 \\
(0.328)\end{array}$ & $\begin{array}{c}-1.019^{* *} \\
(0.399)\end{array}$ & $\begin{array}{c}-0.186 \\
(0.509)\end{array}$ & $\begin{array}{c}-1.572 \\
(1.294)\end{array}$ & $\begin{array}{l}-0.473 \\
(0.346)\end{array}$ & $\begin{array}{c}-0.547 * * \\
(0.233)\end{array}$ & $\begin{array}{c}-0.785^{*} \\
(0.460)\end{array}$ & $\begin{array}{c}2.172 * * * \\
(0.667)\end{array}$ \\
\hline $\begin{array}{l}\text { Observations } \\
\text { R-squared }\end{array}$ & $\begin{array}{c}365 \\
0.032\end{array}$ & $\begin{array}{c}365 \\
0.024\end{array}$ & $\begin{array}{c}365 \\
0.051\end{array}$ & $\begin{array}{c}365 \\
0.070\end{array}$ & $\begin{array}{c}650 \\
0.014\end{array}$ & $\begin{array}{c}651 \\
0.010\end{array}$ & $\begin{array}{c}650 \\
0.022\end{array}$ & $\begin{array}{c}650 \\
0.032\end{array}$ \\
\hline $\begin{array}{l}\text { F-value on LP Type FE } \\
\text { Prob }>|t|\end{array}$ & - & $\begin{array}{l}0.816 \\
0.574\end{array}$ & $\begin{array}{l}0.981 \\
0.445\end{array}$ & $\begin{array}{l}0.726 \\
0.650\end{array}$ & - & $\begin{array}{l}0.522 \\
0.818\end{array}$ & $\begin{array}{l}0.702 \\
0.670\end{array}$ & $\begin{array}{l}0.707 \\
0.666\end{array}$ \\
\hline
\end{tabular}




\section{Table 7: Co-investment net performance under alternative fee scenarios}

This table shows capital-weighted mean net PMEs and net-net PMEs for funds (A) and for co-investments in different fee structure scenarios (B). Fund PMEs (A) are capital-weighted by the fund size measured in USD whereas deal PMEs (B) are capital-weighted by the invested equity measured in USD. We use the three regional MSCI Performance Indices (Asia, Europe, North America) in local currency as benchmarks for our PME calculations and use the regional index where the GP is located. Net fund PMEs are derived by deducting the common fees of fund investments as outlined in Metrick and Yasuda (2010) from the underlying cashflows of the gross PMEs. Net-net fund returns are net fund PMEs minus LPs internal costs of running a fund investment programme as outlined in Fang et al. (2015). Net PMEs for the three different co-investment fee scenarios are derived by deducting the respective fees of each scenario from the underlying cashflows of gross PMEs. Therefore, the net co-investment PME for the "no fee"-scenario equals the gross co-investment PME. For the two remaining scenarios (" $1 / 10$ " and " $0 / 20$ "), the carried interest was calculated in line with Metrick and Yasuda (2010), while the management fees are calculated based on invested equity. Net-net co-investment PMEs are net co-investment PMEs minus LPs internal costs of running a direct investment programme as outlined in Fang et al. (2015). Finally, we match each co-investment with its corresponding fund and calculate the difference between the net (net-net) co-investment PME in different fee scenarios and the corresponding net (net-net) fund PME (C). The means of the PME differences between co-investments and the corresponding fund (C) are capital-weighted by the invested equity of the respective co-investment. The indicator of statistical significance in (B) reports equality of means tests of co-investment and fund returns applying a two-sample t-test. The indicator of statistical significance in (C) results from testing the difference from zero. $* * *$ and $* * *$ denote statistical significance at the $10 \%, 5 \%$ and $1 \%$ level, respectively.

\section{Buyout}

SCENARIOS:

A. Funds:

B. Co-Investments:

No Fees

$1 / 10$

$0 / 20$
365

365

365
$1.76^{* * *}$

$1.59 * * *$

$1.56 * * *$
$1.71 * * *$

$1.54 * * *$

$1.51 * *$
2. Venture Capital

Obs. Net

218

1.29

1.28

\section{Co-Investment minus Fund:}

$\begin{array}{lllllll}\text { No Fees } & 365 & 0.34 * * * & 0.29 * * * & 651 & 0.43 * * * & 0.39 * * * \\ 1 / 10 & 365 & 0.18 * * & 0.13 * * & 651 & 0.26 * * * & 0.23 * * * \\ 0 / 20 & 365 & 0.15 * * & 0.10 * & 651 & 0.23 * * * & 0.19 * * *\end{array}$




\section{Table 8: Portfolio simulations}

This table shows net-net PME return figures of simulated portfolios of fund investments and co-investments. We simulate portfolios by drawing bootstrap samples, i.e. random samples with replacement, from our sample of 1,016 co-investments and 464 corresponding funds. We run 1,000 simulations for each portfolio of 5, 10, 20, 30 and 50 co-investments and fund investments, respectively, and show the mean and median PMEs for the 1,000 portfolios of the respective portfolio size. Panel A shows PMEs for simulated portfolios of buyout fund investments (A.1) and co-investments (A.2), while Panel B shows the same information for VC fund (B.1) and VC co-investments (B.2). We run simulations for all three fee scenarios outlined in Figure 3. Fund investment portfolios are simulated assuming a fee structure as outlined by in Metrick and Yasuda (2010). The indicator of statistical significance reports equality of means (medians) tests of co-investment portfolio and corresponding fund portfolio samples applying a two-sample t-test (sign test). $* * *$ and $* * *$ denote statistical significance at the $10 \%, 5 \%$ and $1 \%$ level, respectively. If put in brackets the difference between co-investment and fund portfolio returns is negative, i.e. is significantly higher for the fund portfolio sample.

\section{Panel A: Buyouts}

\begin{tabular}{|c|c|c|c|c|c|c|c|c|c|c|}
\hline \multirow{3}{*}{ Portfolio Size: } & \multicolumn{10}{|c|}{ PME } \\
\hline & \multicolumn{2}{|c|}{5} & \multicolumn{2}{|c|}{10} & \multicolumn{2}{|c|}{20} & \multicolumn{2}{|c|}{30} & \multicolumn{2}{|c|}{50} \\
\hline & Mean & Median & Mean & Median & Mean & Median & Mean & Median & Mean & Median \\
\hline \multicolumn{11}{|c|}{ A.2 Co-Investment Portfolios } \\
\hline No Fees & $1.75 * * *$ & $1.48 *$ & $1.75 * * *$ & $1.63 * * *$ & $1.72 * * *$ & $1.61 * * *$ & $1.72 * * *$ & $1.63 * * *$ & $1.71 * * *$ & $1.65 * * *$ \\
\hline
\end{tabular}

\section{Panel B: Venture Capital}

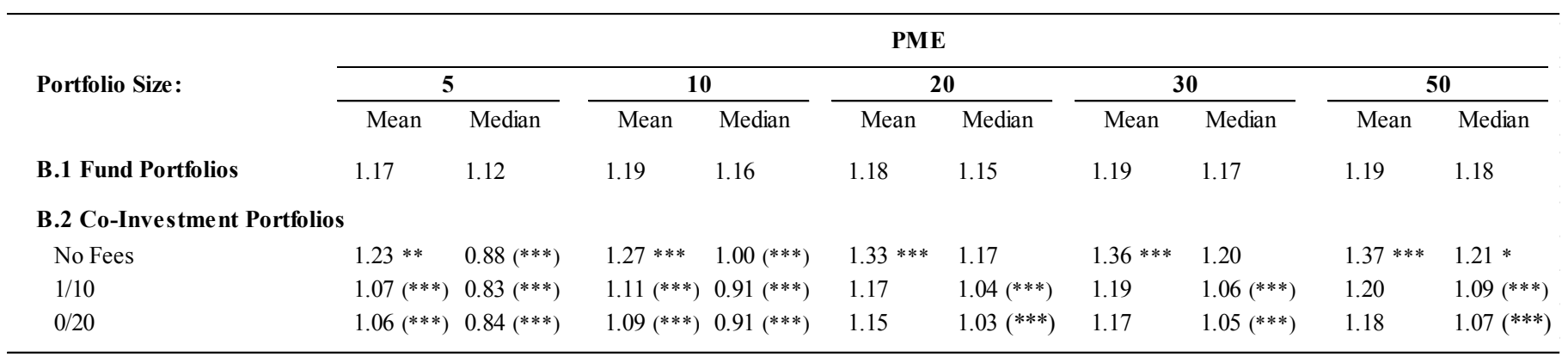




\section{Table 9: Comparison with an alternative LP-sourced sample}

This table shows the mean difference of our co-investment sample' s absolute and relative (to the corresponding fund) PMEs and the corresponding values from an alternative sample. The alternative sample conists of 128 co-investments made by seven LPs before 2011. We account for different weightings of buyout and venture capital deals between the two samples and test whether the differences in absolute and relative PMEs differ from zero. Co-Inv. PME refers to a co-investment's gross PME. Co.-Inv.Fund PME refers to a co-investment's gross PME minus the corresponding fund's gross PME.

\begin{tabular}{|c|c|c|c|c|}
\hline & \multicolumn{2}{|c|}{ Co-Inv. PME } & \multicolumn{2}{|c|}{ Co.-Inv. - Fund PME } \\
\hline & Mean & t-s tat & Mean & t-stat \\
\hline $\begin{array}{l}\text { Diff. (Base Sample - } \\
\text { Alternative Sample) }\end{array}$ & 0.11 & 1.03 & -0.17 & -1.62 \\
\hline
\end{tabular}

